\title{
Spatial Patterns of Heavy Metals in the Sediments of a Municipal Wastewater Treatment Pond System and Receiving Waterbody, Cha am, Thailand
}

\author{
Vicko Andreas, ${ }^{1}$ Kim N. Irvine, ${ }^{2}$ Ranjna Jindal, ${ }^{1}$ Romanee Thongdara, ${ }^{1}$ \\ Nikhil Nath Chatterji ${ }^{3}$ and Wu Bing Sheng ${ }^{4}$ \\ ${ }^{1}$ Mahidol University, Thailand; ${ }^{2}$ National Institute of Education and Nanyang Environment and Water Research Institute, Nanyang Technological \\ University, Singapore; ${ }^{3}$ National Institute of Education, Singapore; ${ }^{4}$ National Taiwan Normal University, Taipei, Taiwan.
}

\begin{abstract}
Cha am, a popular beach destination in Thailand, uses an aerated lagoon system with four ponds in series to treat its municipal wastewater. This study investigated the spatial pattern of heavy metal concentrations in the sediment deposited at the bottom of the four ponds and along the river receiving the treated wastewater discharge. Using a stratified random sampling scheme, between 11 and 14 surface grab samples were collected from each of the four ponds on two different dates in September and October 2016 (94 samples in total). An additional 17 samples were collected in December 2016 along the $1.8 \mathrm{~km}$ river section connecting the ponds to the ocean. A Bruker S1 Titan 600 X-ray fluorescence (XRF) analyser was used to determine metal concentrations in the air dried sediment samples. Ordinary kriging in ArcGIS10.1 indicated that while metal concentrations were greater in the middle areas of each pond, from pond to pond the metal concentrations exhibited different spatial trends. The ponds provide treatment for most of the metals analysed, with Student $t$-tests showing that mean concentrations of arsenic, chlorine and zinc decreased significantly from the first pond to the third pond but increased significantly in the fourth pond. Chromium concentration changed insignificantly between ponds; lead concentration decreased significantly from the first to the second pond, but there were insignificant changes in mean lead concentration thereafter. Concentrations of cadmium, cobalt, mercury and selenium were below the XRF limit of detection, but the mean levels of arsenic, chromium, copper, lead and manganese in each of the four ponds frequently exceeded Ontario Ministry of the Environment and Climate Change lowest effect level (LEL) guidelines for sediment. Metal levels in the upper reach of the river, closest to the pond discharge, were similar to the pond levels and generally decreased downstream. With the exception of zinc, metal levels detected in the river sediment frequently exceeded the LEL guidelines.
\end{abstract}

\section{Introduction}

Because of its quiet and restive atmosphere, a $7 \mathrm{~km}$ long beach, and a wide range of accommodations and restaurants, Cha am, Thailand has become a popular tourist destination for both international and local Thai visitors. The population of Cha am in 2016 was reported to be 49375 . In 2001, Cha am municipality constructed an aerated lagoon (pond) system which consists of four oxidation ponds in series: an aeration pond, a settling pond, an extended aeration pond and an evaporation pond. Since tourism is an important component of the local economy and the scenic public beach is central to this tourism, it is essential to manage wastewater discharges appropriately. Past studies (e.g. But et al. 2016; Bhowmick et al. 2017; Koko et al. 2017) have examined the water quality and the efficiency of the pond system in managing conventional wastewater parameters such as chemical oxygen demand (COD), total suspended solids (TSS), total Kjeldahl nitrogen (TKN), E. coli and dissolved oxygen, but to date no evaluations have assessed levels of metals in the ponds. The objectives of this study were therefore: to examine the spatial variation of metals levels, longitudinally, from the ponds on through the receiving river channel system, to the ocean; to compare metal levels in the ponds to those in the upper reach of the receiving river to assess the pond system as a source area; and to compare metal levels in the ponds and river with sediment quality guidelines to provide a first indication of environmental risk.

Although trace metals, including copper (Cu), zinc (Zn), manganese (Mn), arsenic (As), chromium ( $\mathrm{Cr}$ ) and vanadium (V) are essential components of biological functions at low levels, at higher levels metal contamination becomes a global concern 
because of potential harmful effects on aquatic ecosystems and human health (e.g. Zhou et al. 2008; Khan et al. 2008; Förstner and Wittmann 2012; Tchounwou et al. 2012; Wang et al. 2013; Bjerregaard et al. 2015; Islam et al. 2015). In this study, we denote metals with a density $>5 \mathrm{~g} / \mathrm{cm}^{3}$ as heavy metals. Suciu et al. (2008) indicated that there are 60 such known metals in the earth-atmosphere system. Sparks (2005) noted that the term heavy metals is normally associated with issues of pollution and toxicity, even though some heavy metals are required by organisms at trace levels. Metal cycling in the environment is complex and includes emission, storage, and transformation in the atmosphere, geosphere and hydrosphere. Emissions may result from natural sources, such as biogeochemical weathering of rocks and soils or volcanic eruptions, as well as from a host of anthropogenic activities, including the combustion of fossil fuels, mining, industrial processing, transportation, industrial and municipal waste discharges, agricultural production, and urban runoff (Vermette et al. 1987; Nriagu and Pacyna 1988; Garrett 2000; Pacyna and Pacyna 2001; Irvine et al. 2005; Taylor and Owens 2009; Chen et al. 2015; Kibria et al. 2016; Nasirian et al. 2016).

It has long been known that metals preferentially adsorb to particulate matter (Förstner 1987; Förstner et al. 1990; Horowitz 1991; Gunawardana et al. 2014) and many studies have shown that up to $90 \%$ of the heavy metal loads in river systems may be particle bound (Förstner and Salomons 1980; Calmano et al. 1993; Walling et al. 2003). In a manner similar to river systems, wastewater sediment or sludge also can preferentially adsorb metals (Karvelas et al. 2003; Garcia-Delgado et al. 2007). While this propensity for adsorption can facilitate wastewater treatment through settling, the challenge of managing the subsequent sludge remains. Management options have historically included landfill, incineration, and use as an agricultural amendment due to high nutrient levels in the sludge. Concerns about the effects of metals contained in sludge on agricultural soils and crops have been raised in both developed and developing countries (McBride 2003; Jamali et al. 2009; Tiwari et al. 2011; Kumar et al. 2014; Latare et al. 2014), so it is important to monitor the metal levels in sludge when making decisions related to its use as an agricultural amendment.

Over the past 20 years, Thailand has constructed 101 municipal wastewater treatment plants throughout the country and the combined capacity of these plants is 3.2 million $\mathrm{m}^{3} / \mathrm{d}$ (Chokewinyoo and Khanayai 2013). Among these plants, $45 \%$ are stabilization ponds, $32 \%$ are activated sludge, $16 \%$ are aerated lagoons, $2 \%$ are constructed wetlands and $1 \%$ are rotating biological contactors. Because aerated lagoon treatment is not uncommon in Thailand, results for the case study of Cha am might be useful for other locations. Aerated lagoons, similar in design to Cha am, have been shown effective in treating conventional wastewater parameters, including nutrients, suspended sediment, COD and E. coli, although performance varies by design and operational characteristics (Al-Sa'ed 2007; Li et al. 2013; But et al. 2016; Von Sperling and de Lemos Chernicharo 2017, 857). But et al. (2016) found the Cha am ponds were particularly effective in reducing TKN levels (83.2\%) and E. coli (99.99\%) between influent and effluent, but were less effective in reducing suspended solids and COD.

\section{Methodology}

\subsection{Study Area and Data Collection}

The Cha am municipal wastewater collection system is a combined system with average flows to the treatment ponds ranging between $3000 \mathrm{~m}^{3} / \mathrm{d}$ and $5000 \mathrm{~m}^{3} / \mathrm{d}$ during the dry season and $>10000 \mathrm{~m}^{3} / \mathrm{d}$ in the rainy season. The wastewater treatment ponds are located $\sim 3 \mathrm{~km}$ north of the municipal area and receive wastewater discharges (as well as stormwater runoff) from the residential and commercial zones of the town (Figures 1 and 2). The aerated lagoon treatment system consists of four ponds: an aeration pond, a settling pond, an extended aeration pond, and an evaporation pond, which is part of the original wetland system in the area. Bhowmick et al. (2017) provide more detail on pond configuration and operation, but briefly the surface area and depths of each pond were: aeration pond (Pond 1): surface area $40082 \mathrm{~m}^{2}$, depth $2.5 \mathrm{~m}-2.8 \mathrm{~m}$; settling pond (Pond 2): surface area $16452 \mathrm{~m}^{2}$, depth $2.3 \mathrm{~m}-2.5 \mathrm{~m}$; extended aeration pond (Pond 3): surface area $48522 \mathrm{~m}^{2}$, depth 1.7-1.8 m; and evaporation pond (Pond 4): surface area $323612 \mathrm{~m}^{2}$, depth $2.0 \mathrm{~m}-2.3 \mathrm{~m}$.

Cha am municipality has estimated the hydraulic retention time for the entire treatment system to be in the range of 2 weeks-3 weeks, although the water budget for the system is quite dynamic. Over a several month period in the rainy season it seems that about $59 \%$ of the water entering the ponds as runoff and direct rainfall evaporated. This percentage would increase in the dry season.

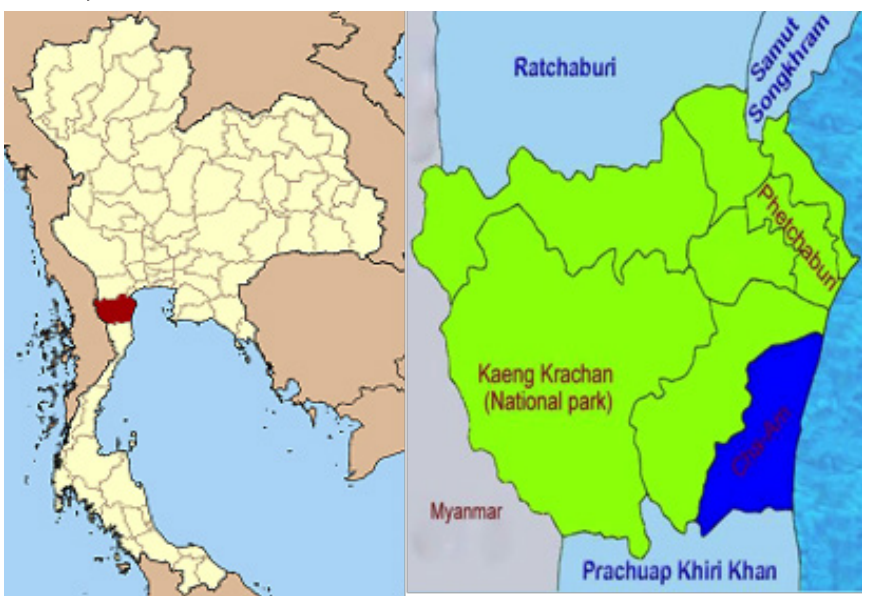

Figure 1 Thailand and location of Cha am. 


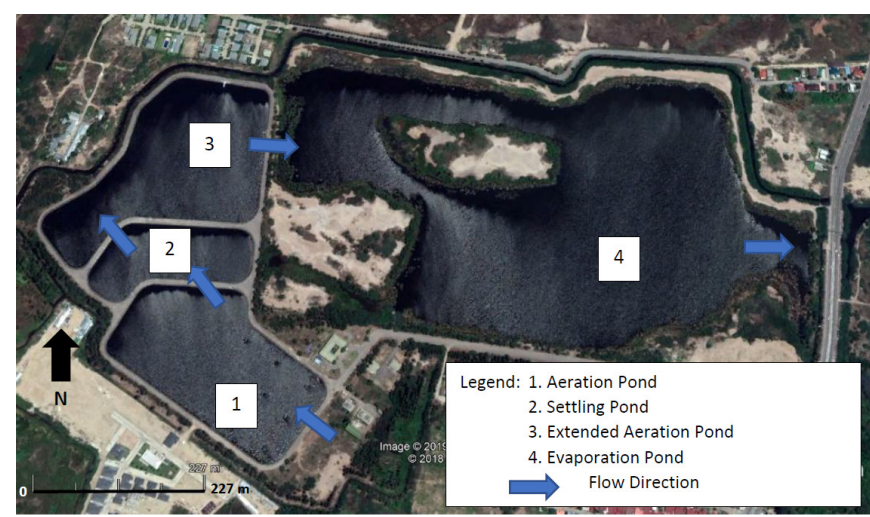

Figure 2 Cha am municipal wastewater treatment pond system and flow direction.

A small river which ultimately discharges to the ocean receives the aerated lagoon effluent. The river meanders slightly and generally increases in width (from $\sim 8 \mathrm{~m}$ to $30 \mathrm{~m}$ ) and depth (from $\sim 0.07 \mathrm{~m}$ to $0.4 \mathrm{~m}$ ) as it progresses towards the ocean (Figure 3). The tidal range in this area of the Gulf of Thailand is small, with the maximum observed range in Cha am being $\sim 2.86 \mathrm{~m}$. Land use along the river is a mix of open land (some of which was formerly aquaculture ponds now infilled for development), newly constructed gated communities and townhouses set back from the river, traditional housing on the river banks, institutional (school and temple), commercial areas (restaurants, hotels, shops), and pockets of forest (including mangrove). Wastewater from the urban areas north of the river does not drain to the aerated lagoon but rather discharges directly into the river.

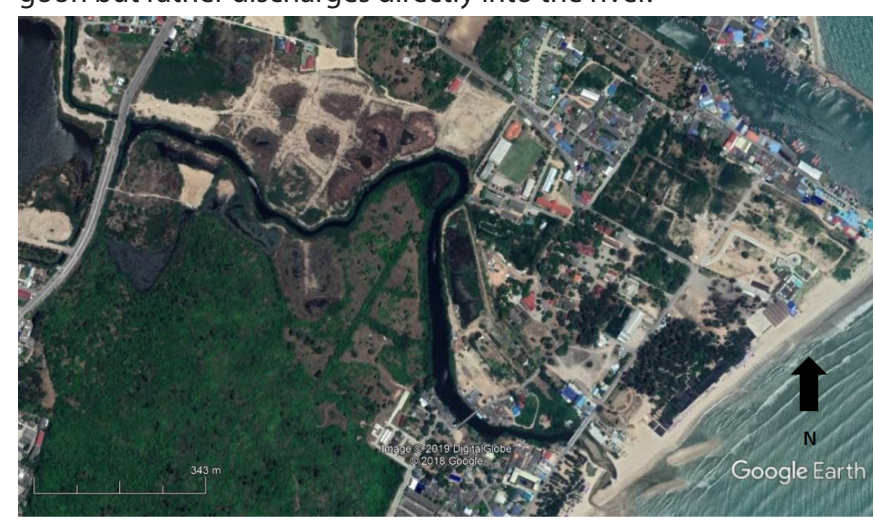

Figure 3 A small river connects treatment ponds to the ocean; bare land to the north is the infill from previous aquaculture ponds.

Sample locations in the ponds were determined using a stratified random approach, an example of which is shown in Figure 4. A stratified random sampling approach is frequently employed to collect environmental samples over a study area (Ferguson 1992; Caeiro et al. 2003; Ning et al. 2006; McGrew and Monroe 2009; Tóth et al. 2016). In this approach, collecting samples within the spatially-distributed grid cells helps to ensure the entire pond area is represented, but the random location of the sample within each cell helps to preserve the unbiased structure of the data set, which is desirable in statistical analysis.

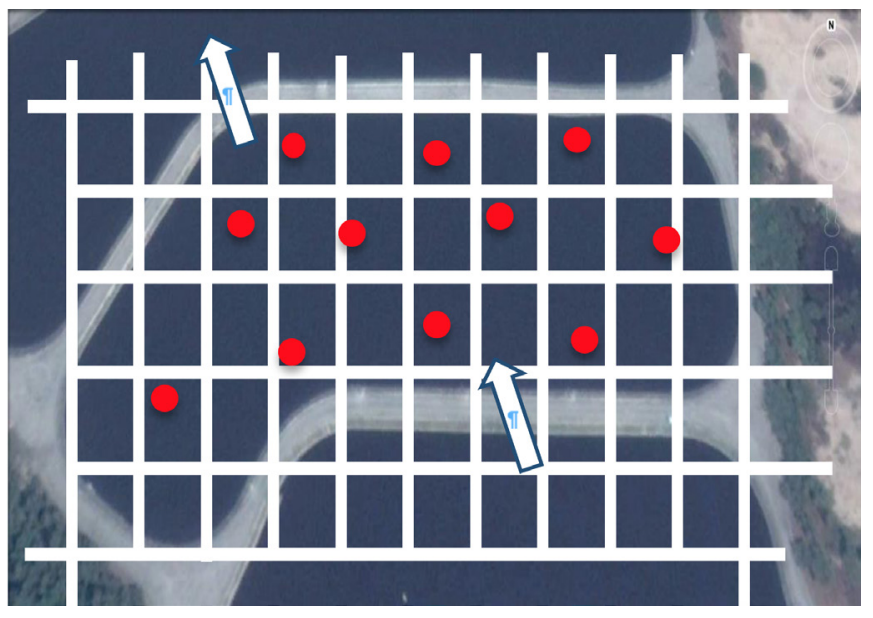

Figure 4 Stratified random sample scheme for sedimentation pond, with sample sites shown as red circles (a similar sampling scheme was used for other ponds).

Samples were collected in two different rounds, the first round on 2016-09-25-26 and the second round on 2016-10-0809. The number of samples collected in each round for each pond is summarized in Table 1. The samples were obtained from the upper $3 \mathrm{~cm}-5 \mathrm{~cm}$ layer of the bed sediment using a Mighty Grab dredge device (78-080 Fieldmaster from Science First Corporation), with approximately $1 \mathrm{~kg}$ (wet weight) of sediment collected from each sample site.

Table 1 Number of samples taken from each pond on each sample date.

\begin{tabular}{|c|c|}
\hline Name of Pond & Number of Samples \\
\hline Aeration pond & 11 \\
\hline Settling pond & 11 \\
\hline Extended aeration pond & 11 \\
\hline Evaporation pond & 14 \\
\hline Total & 47 \\
\hline
\end{tabular}

Samples of the riverbed sediment were collected from a small boat on 2016-12-15-16. The dredge used for pond sampling was not heavy enough to sink into the river sediment and therefore was unsuitable for river sampling. Instead, sediment samples from the upper $5 \mathrm{~cm}-7 \mathrm{~cm}$ of the riverbed were collected by driving a length of PVC tube into the sediment and extruding the cores once they were secured safely on the boat. This approach required several cores to be collected and composited in each immediate area to obtain $\sim 150 \mathrm{~g}$ (wet weight) of sediment, an amount sufficient for metals analysis. Samples were collected from a total of 17 locations along the river. Where the width of the river warranted, samples were collected on a transect at onethird, mid-channel, and two-thirds locations across the channel. Otherwise, samples were collected at mid-channel. 


\section{$2.2 \mathrm{pH}$ and Temperature Analysis}

A portable meter (HM-20P, KK-TOA Corporation) from the Water Quality Laboratory in the Faculty of Engineering, Mahidol University was used to measure the $\mathrm{pH}$ and the temperature of the treatment pond sediment samples. Insufficient volume of sediment was obtained from the river sites to conduct this analysis.

\subsection{Particle Size Analysis}

Samples from the treatment ponds were air dried and then oven dried for $24 \mathrm{~h}$ at $105^{\circ} \mathrm{C}$. The samples were subsequently hand ground with porcelain mortar and pestle and dry sieved for size analysis, following Bowles (1986). The raw size data were analysed using the GRADISTAT add-in for Excel (Blott and Pye 2001). Insufficient mass was collected for the river samples to be analysed in this way.

\subsection{Metal Analysis by X-Ray Fluorescence}

All sediment samples (pond and river) were analysed using a handheld Bruker S1 Titan 600 X-Ray Fluorescence (XRF) system in Singapore. XRF is a non-destructive analytical method that requires no pre- or post-chemistry and delivers the concentrations of a suite of metals (much like ICP analysis) in a short run time. A large number of samples can be processed, which is ideal for geospatial analysis of contaminants. XRF analysis is not as commonly used for metals analysis as atomic absorption spectrometry (AAS) or inductively coupled plasma analysis (ICP), but it has been applied in studies as diverse as the assessment of contaminants in sediments, soils, atmospheric dust, household paints, skin whitening creams, trace element levels in alloys and geological materials, and the evaluation of art and archaeological specimens (Rhoads and Cahill 1999; Mantler and Schreiner 2000; Szökefalvi-Nagy et al. 2004; Vittiglio et al. 2004; Lawryk et al. 2009; Apeagyei et al. 2011; Diaz et al. 2014; Shuttleworth 2014; Charlou et al. 2014; Murphy et al. 2015; Lim et al. 2015; Sereyrath et al. 2016; Murphy et al. 2018). Radu and Diamond (2009) showed a good correlation between XRF and AAS analysis of metals in soil samples, while Murphy et al. (2012) showed a good correlation between XRF and ICP-OES analysis of skin whitening creams.

The sediment samples were air dried thoroughly prior to analysis and any visible organic material was carefully removed. The samples were then ground with mortar and pestle. Normally about $7 \mathrm{~g}$ (dry weight) of sediment was placed in each XRF sample cup until full and the cup was then sealed with ultralene film. For a few samples not enough sediment was available to fill the cup and additional quality assurance-quality control (QA-QC) procedures, outlined below, were conducted to address this issue. The XRF unit was set to the soils mode library and the run time was $2 \mathrm{~min} / \mathrm{sample}$.

For QA-QC purposes certified reference material was analysed at the start of each analytical batch. The certified reference material was either the NIST SRM2710X (Montana I soils) or the CS-M2 soil from Bruker. Additional QA-QC was done by randomly selecting three pond samples and re-analysing each with four different sample sizes $(7 \mathrm{~g}, 6 \mathrm{~g}, 5 \mathrm{~g}$ and $4 \mathrm{~g})$ to compare with the full cup results. Two other pond samples were re-analysed after a $2 \mathrm{~d}$ hold period in the sample cup.

\subsection{Spatial Analysis of Heavy Metal Concentra- tions Using GIS Kriging}

The geographic coordinates for each sample location were converted to a shapefile using ArcView3.3. The ArcGIS10.1 Geostatistical Analyst tool (kriging Interpolation) was then used to spatially interpolate metal concentrations based on the sample points. A variety of geospatial interpolation techniques are available in addition to kriging, including spline, natural neighbour, trend surface analysis, random forest, and support vector machine ( $\mathrm{Li}$ and Heap 2014). Studies have indicated that kriging generally provides better results than spline and natural neighbour analysis (Voltz and Webster 1990; Laslett 1994; Pavão et al. 2012; Duong and Gourbesville 2014). Different kriging approaches have been developed (Li and Heap 2014; Forsythe et al. 2013; 2015) but ordinary kriging (OK) has been widely applied (Isaaks et al. 1989; Robertson 2008; Soffianian et al. 2015; Koko et al. 2017) and was used here for the ponds and river. The general equation for estimating a value at a point $z$ (Chang 2012) is:

$$
z_{0}=\sum_{i=1}^{s} z_{x} W_{x}
$$

where:

$z_{0}=$ the estimated value,

$z_{x}=$ known value at point $x$,

$W_{x}=$ the weight associated with point $x$, and

$s=$ number of sample points used in estimation.

The weights can be derived by solving a set of simultaneous equations (Equations 2, 3 and 4). For example, the following equations are needed for a point ( 0 ) to be estimated from three known points (1, 2 and 3);

$$
\begin{aligned}
& W_{1} \gamma\left(h_{11}\right)+W_{2} \gamma\left(h_{12}\right)+W_{3} \gamma\left(h_{13}\right)+\lambda=\gamma\left(h_{10}\right) \\
& W_{1} \gamma\left(h_{21}\right)+W_{2} \gamma\left(h_{22}\right)+W_{3} \gamma\left(h_{23}\right)+\lambda=\gamma\left(h_{20}\right) \\
& W_{1} \gamma\left(h_{31}\right)+W_{2} \gamma\left(h_{32}\right)+W_{3} \gamma\left(h_{33}\right)+\lambda=\gamma\left(h_{30}\right)
\end{aligned}
$$

and

$$
W_{1}+W_{2}+W_{3}=1
$$

where:

$$
\begin{aligned}
\gamma= & \text { semivariance between two known points, and } \\
\lambda= & \text { Lagrange multiplier or the weighting factor } \\
& \text { (which is added to ensure the minimum possible } \\
& \text { estimation error). }
\end{aligned}
$$

After solving the weights, Equation 1 can be used to estimate ' $z_{0}$ ':

$$
z_{0}=z_{1} W_{1}+z_{2} W_{2}+z_{3} W_{3}
$$




\section{Results and Discussion}

\subsection{Temperature and $\mathrm{pH}$ Measurements in Waste- water Treatment Ponds}

July through October is the rainy season in Thailand and in September 2016 there was plentiful rainfall throughout the country. The temperature in Thailand was $0.5^{\circ} \mathrm{C}$ higher than normal and the average temperature in Cha am was $28.7 \pm 0.5^{\circ} \mathrm{C}$. Thailand again was warmer and wetter than normal in October 2016, with the average temperature in Cha am being $28.1 \pm 0.4^{\circ} \mathrm{C}$ (TMD 2016a; 2016b).

The minimum temperature of the sediment from the first sample date was $29.7^{\circ} \mathrm{C}$ in the extended aeration pond and the maximum was $31.2^{\circ} \mathrm{C}$ in the evaporation pond. The minimum value of $\mathrm{pH}$ from the first sample date was 6.51 in the aeration pond and the maximum was 7.4 in the extended aeration pond. The minimum temperature of the sediment from the second sample date was $29.7^{\circ} \mathrm{C}$ in the extended aeration pond and the maximum was $31.4^{\circ} \mathrm{C}$ in the settling pond. The minimum value of $\mathrm{pH}$ from the second sample date was 6.44 in the aeration pond and the maximum was 7.31 in the evaporation pond.

The sewage sludge $\mathrm{pH}$ from sampled wastewater treatment plants in China was reported as ranging between 4.4 and 7.7 (Wang et al. 2005), while the $\mathrm{pH}$ of textile dyeing sludge may range between 6.20 and 8.90 (Liang et al. 2013). Table 2 shows the correlation between the mean $\mathrm{pH}$ in the four ponds and the mean metal concentrations.

Table 2 Correlation between overall mean $\mathrm{pH}$ and metal concentrations in the sediment samples from the two sample dates.

\begin{tabular}{ccc}
\hline \multirow{2}{*}{ Heavy Metal } & \multicolumn{2}{c}{ Correlation $(r)(\mathrm{pH})$} \\
& 1st Sample Date & 2nd Sample Date \\
\hline As & -0.7474 & -0.5487 \\
$\mathrm{Cl}$ & -0.7930 & -0.4888 \\
$\mathrm{Cu}$ & -0.8160 & -0.8999 \\
$\mathrm{Zn}$ & -0.8088 & -0.8543 \\
$\mathrm{~Pb}$ & -0.7721 & -0.9052 \\
$\mathrm{Cr}$ & 0.3982 & 0.6475 \\
$\mathrm{Mn}$ & 0.7073 & 0.2726 \\
\hline
\end{tabular}

From Table 2, average concentrations of $\mathrm{As}, \mathrm{Cl}, \mathrm{Cu}, \mathrm{Zn}$ and $\mathrm{Pb}$ show a negative relationship with average $\mathrm{pH}$. A number of studies also have found a negative correlation between metal concentrations and pH (Perez-Esteban et al. 2014; Pereira et al. 2016; Khaledian et al. 2017). While $\mathrm{pH}$ is an important factor controlling the bioavailability of metals, sediment texture, aluminium and iron oxides, and organic matter (OM) also play a role (Khaledian et al. 2017). Some metals show a positive relationship with average $\mathrm{pH}$ such as $\mathrm{Cr}$ and $\mathrm{Mn}$. The weakest correlation between metal and $\mathrm{pH}$ was for $\mathrm{Mn}$ on the second sample date. The environment can affect $\mathrm{pH}$ during the rainy season in Cha am by impacting the minerals and microorganisms contained in the sediments. Table 2 suggests that it is important to control pond $\mathrm{pH}$; should the $\mathrm{pH}$ become too acidic, metals can be released from the sediment.

\subsection{Comparison between Overall Mean Particle Size $\left(D_{50}\right)$ in the Sediment in Wastewater Treatment Ponds}

Figure 5 compares the averaged median particle size $\left(D_{50}\right)$ for the first and second sampling dates. Generally, the results for the two sample dates are similar except, perhaps, for the aeration pond. Sizes in Figure 5 also are within a similar range to that reported by Schmitt et al. (2011) for a wastewater treatment plant and sewer system in France $(20 \mu \mathrm{m}-500 \mu \mathrm{m})$.

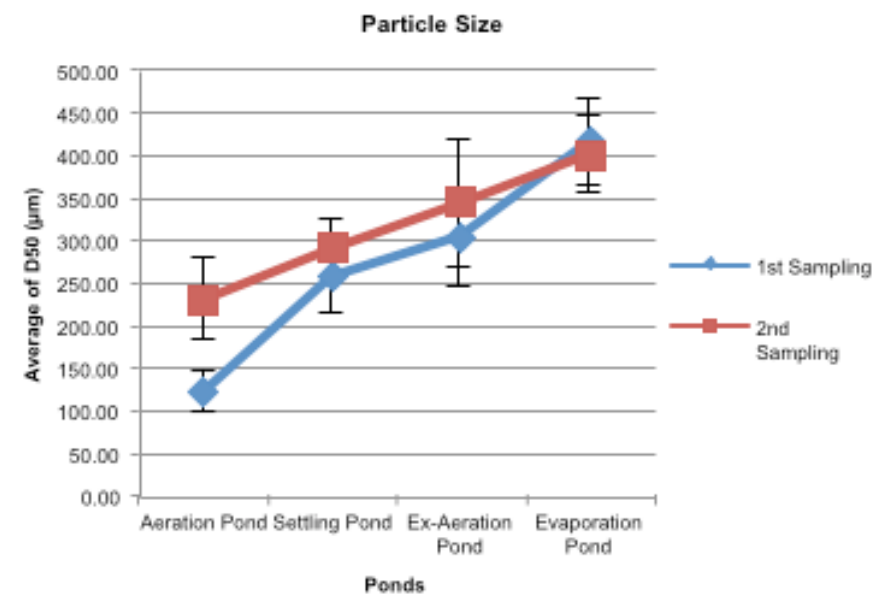

Figure 5 Comparison of particle size $\left(D_{50}\right)$ averages from the two sample dates.

The averaged median particle size $\left(D_{50}\right)$ from both sample dates increased significantly (Student $t$-test, $a=0.05$ ) from the aeration pond to the evaporation pond. However, given the general characteristics of hydraulic sorting we would expect a fining from the aeration pond to the evaporation pond, which did not occur. Digestion processes in sludge or sediment influence particle size (Martinez et al. 2015). Particle size distribution will vary with field location (spatially), rainfall intensity (hydrologically), and dry season (temporally; Gulliver et al. 2010). Other factors also can affect the particle size of sediment at Cha am, such as the weather, human activity in the ponds (e.g. fishing, recreational boating in the evaporation pond), and local erosion of the soil, especially in the vicinity of the evaporation pond.

The condition of the dried sediment differed between ponds. There were no gravels contained in the sediment from the aeration pond. However, the sediment from the settling pond, extended aeration pond, and evaporation pond had increasing gravel content. The sediment from the evaporation pond also contained small pieces of shells that can affect the measurement of particle size. 
Wastewater sediment is normally flocculated (Droppo et al. 1996; Liao et al. 2002; Li and Yang 2007; Yu et al. 2008) and it was expected that this would be the case for the wastewater sediment entering the aeration pond. Droppo et al. (2002) showed that street sediment generally is not flocculated, but during storm events the entrained sediment starts to flocculate in the street gutters, and flocculation occurs to an even greater extent within a combined sewer system during storm events. They also found that the larger the combined sewage floc size, the greater the settling velocity.

Flocs are a complex of organic material, extracellular polymeric substances, and discrete (smaller) mineral particles. Droppo et al. (2002) observed that when flocs were sonicated $D_{50}$ decreased considerably, essentially because the primary particles were being measured. The unexpected trend of increasing $D_{50}$ from aeration pond to evaporation pond may have resulted from a combination of factors, including (1) local inputs of gravel to the ponds from surrounding areas due to storm runoff and (2) the seemingly different behaviour of the evaporation pond, which is larger and part of the original natural wetland system of the area.

But et al. (2016) noted a slight increase in E. coli levels at the outlet of the evaporation pond (as compared to the extended aeration pond outlet) and Koko et al. (2017) reported that dissolved oxygen is consistently higher at the inlet compared to the outlet of the pond (which is opposite to the trend in the extended aeration pond). This difference in behaviour may occur due to localized runoff inputs (and is therefore linked to factor 1) and because flocculated sediment entering the aeration pond would have a greater settling velocity than the individual mineral particles that make up the floc. However, the bottom sediment size analysis was done by dry sieving in this study and this method measures the size of discrete particles, not flocs. An unexpectedly large proportion of finer mineral matter may have settled in the aeration pond due to flocculation and the sieving is therefore reflecting a higher relative composition of fine particles.

\subsection{Comparison between Mean Heavy Metal Lev- els in the Wastewater Treatment Ponds}

Mean metal levels in the sediment of each pond were calculated for both sample dates and the results are summarized in Figures 6 through 12. The figures also indicate the lowest effect level (LEL) for each metal (with the exception of $\mathrm{Cl}$, for which there is no defined LEL) as determined by Ontario Ministry of Environment and Energy (MOEE 1993). LEL represents a level of contamination below which there is no effect on the majority of sediment-dwelling organisms and is therefore considered to be clean to marginally polluted.

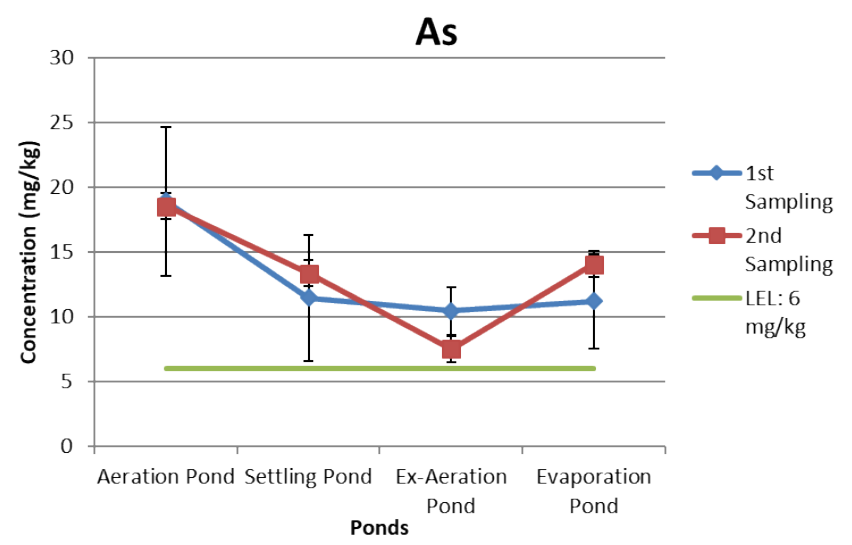

Figure 6 Comparison of mean As concentrations in the sediment in the four ponds from the two sample dates.

Cl

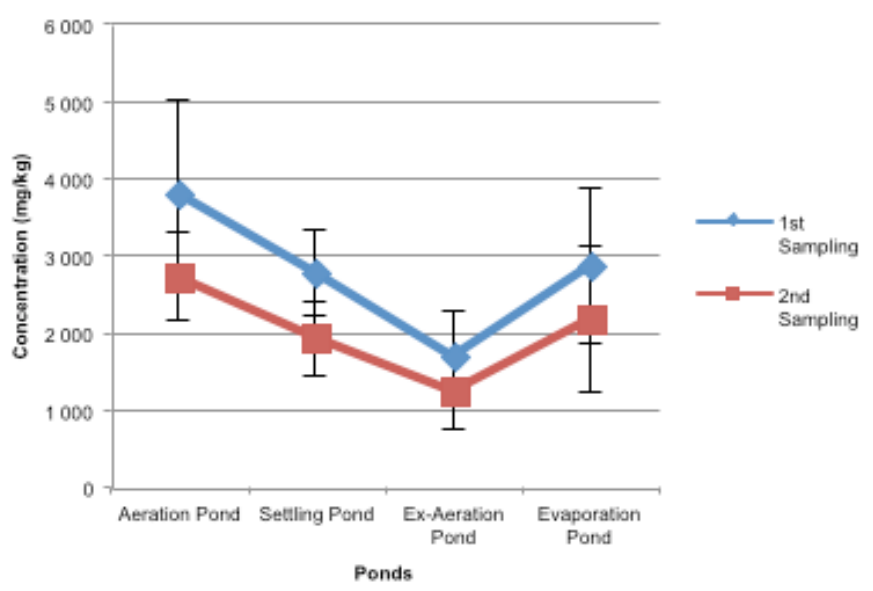

Figure 7 Comparison of mean $\mathrm{Cl}$ concentrations in the sediment in the four ponds from the two sample dates.

Zn

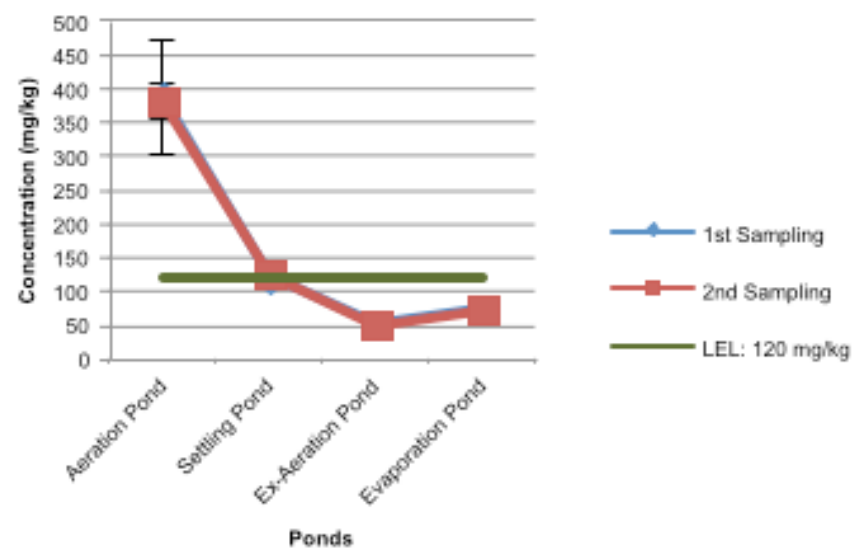

Figure 8 Comparison of mean $\mathrm{Zn}$ concentrations in the sediment in the four ponds from two sample dates. 
$\mathrm{Cr}$

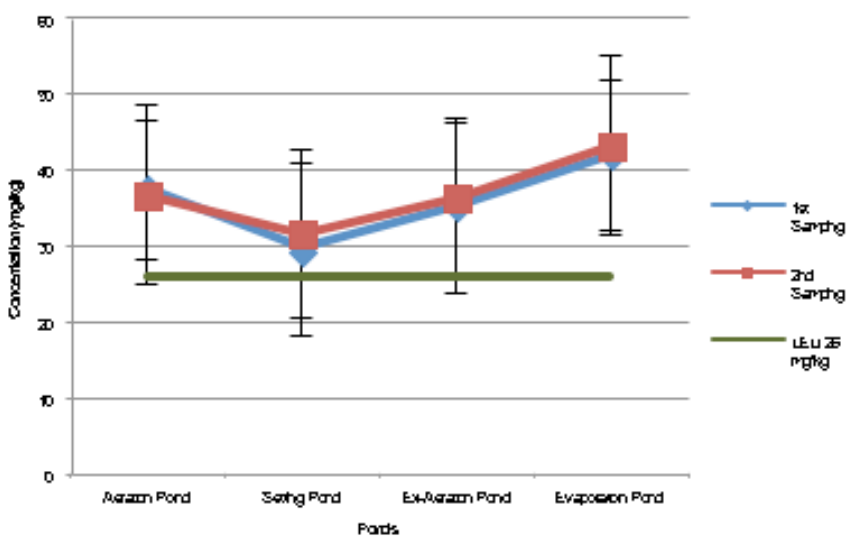

Figure 9 Comparison of mean $\mathrm{Cr}$ concentrations in the sediment in the four ponds from the two sample dates.

$\mathrm{Cu}$

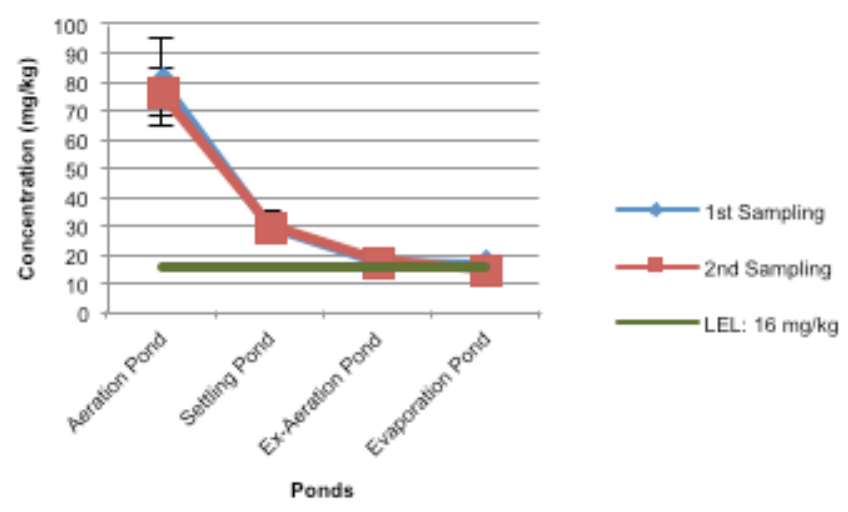

Figure 10 Comparison of mean $\mathrm{Cu}$ concentrations in the sediment in the four ponds from the two sample dates.

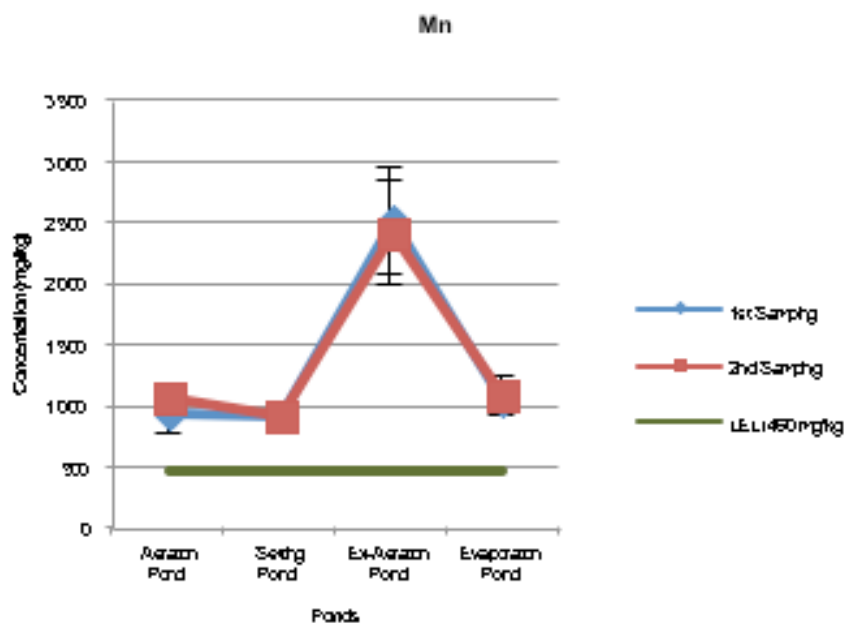

Figure 11 Comparison of mean Mn concentrations in the sediment in four ponds from the sample dates.
$\mathrm{Pb}$

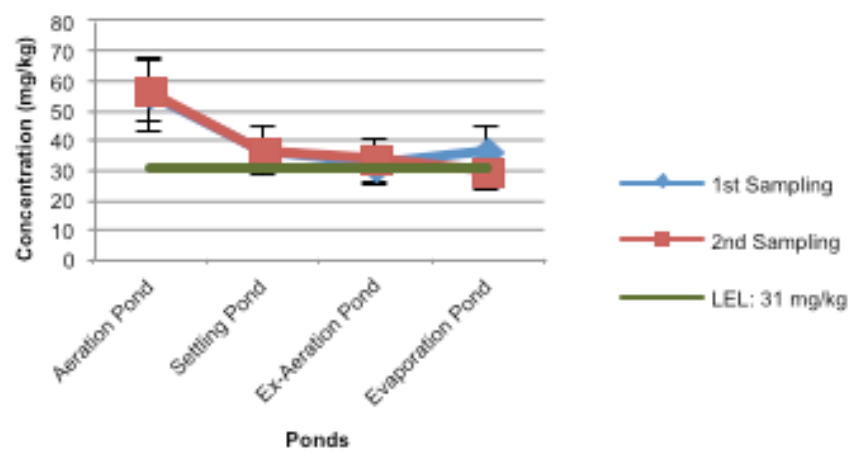

Figure 12 Comparison of mean $\mathrm{Pb}$ concentrations in the sediment in the four ponds from the two sample dates.

With the exception of $\mathrm{Cl}$, the results for mean metals levels between the first and second sample dates are remarkably similar. The level of $\mathrm{Cl}$ may differ due to variable seawater intrusions into the collection system, as noted by But et al. (2016). In comparison with LEL, results in Figures 6-12 showed:

- mean As, Cr and Mn levels exceeded LEL in all ponds for both sample dates;

- mean Zn levels exceeded LEL in the aeration pond for both sample dates but were below LEL for the extended aeration and evaporation ponds;

- mean Cu levels exceeded LEL in the aeration, settling and extended aeration ponds for both sample dates but were less than LEL in the evaporation pond; and

- mean concentrations of Pb exceeded LEL in the aeration, settling and extended aeration ponds for both sample dates, but were at or below LEL in the evaporation pond.

Qualitatively, some of the mean metal levels appear to exhibit a decreasing trend from aeration pond through evaporation pond, while $\mathrm{Cr}$ levels seem to increase. Student $t$-tests were performed and the results ( $a=0.05)$ can be summarized as:

- As, $\mathrm{Cl}, \mathrm{Zn}$ and Cu levels decreased significantly from aeration pond to settling pond for both sample dates;

- Pb levels decreased significantly from aeration pond to settling pond for the first sample date but not for the second, whereas Mn levels decreased significantly for the second sample date but not the first;

- from settling pond to extended aeration pond, $\mathrm{Cl}, \mathrm{Zn}$ and $\mathrm{Cu}$ levels decreased significantly for both sample dates, As levels decreased significantly for the second sample date but not the first, and Mn levels showed an opposite trend, increasing significantly for both sample dates;

- Cl and Zn levels increased significantly from extended aeration pond to evaporation pond for both sample dates, while As increased significantly for the second sample date; and 
- although $\mathrm{Cr}$ levels seemed to increase through the last three ponds, because of the high variability, this trend was not significant.

Concentrations of $\mathrm{As}, \mathrm{Cu}, \mathrm{Zn}, \mathrm{Cr}$ and $\mathrm{Pb}$ for all samples were lower than the severe effect level (SEL) in each pond from both sample dates. However, Mn concentrations were higher than SEL in the aeration pond in one sample from the first sample date and three samples from the second sample date. All samples from the settling pond exhibited Mn concentrations lower than the SEL guideline, while all samples on both sample dates from the extended aeration pond had Mn concentrations higher than the SEL guideline. In the evaporation pond, five samples from the first sample date and seven samples from the second sample date exceeded the SEL guideline for $\mathrm{Mn}$. There is no SEL guideline for $\mathrm{Cl}$.

\subsection{Correlation between Particle Size $\left(D_{50}\right)$ and}

\section{Heavy Metal Concentrations in the Sediment}

Pearson product moment correlation analysis was used to analyse correlations between sediment $D_{50}$ and metals levels. The results are shown in Table 3. $D_{50}$ was significantly correlated ( $a=0.05$ ) with levels of $\mathrm{As}, \mathrm{Cu}, \mathrm{Zn}$ and $\mathrm{Pb}$ but not $\mathrm{Mn}, \mathrm{Cl}$ or $\mathrm{Cr}$. Although desirable, we did not directly analyse the metals levels in different sediment size classes. Studies have frequently shown finer sediment sizes are associated with higher metal concentrations, in part as a result of clay mineralogy and adsorption (e.g. Förstner and Salomons 1980; Singh et al. 1999; Murray et al. 1999; Maslennikova et al. 2012) and the negative correlation results in our study generally are consistent with this size trend.

Table 3 Correlation between the overall mean particle size $\left(D_{50}\right)$ and metals concentrations in the sediment samples from the two sample dates.

\begin{tabular}{ccc}
\hline Heavy Metal & \multicolumn{2}{c}{ Correlation $(r)$ (Particle Size) } \\
& 1st Sample Date & 2nd Sample Date \\
\hline As & -0.8330 & -0.5569 \\
Cl & -0.5516 & -0.4966 \\
Cu & -0.9005 & -0.9002 \\
Zn & -0.8700 & -0.8555 \\
$\mathrm{~Pb}$ & -0.7948 & -0.9040 \\
$\mathrm{Cr}$ & 0.3727 & 0.6480 \\
$\mathrm{Mn}$ & 0.2149 & 0.2861 \\
\hline
\end{tabular}

\subsection{GIS Ordinary Kriging Interpolation: Treat-} ment Ponds

Ordinary kriging (OK) was used to assess spatial patterns of metals in each pond. Unlike the kriging results reported by Koko et al. (2017) for the ponds where there were regular spatial patterns for dissolved oxygen, it is more difficult to generalize about the spatial patterns for metals in the sediment. The spatial patterns of $\mathrm{Cu}$ and $\mathrm{Pb}$ concentrations in the sediments from the aeration pond are shown in Figures 13 and 14.

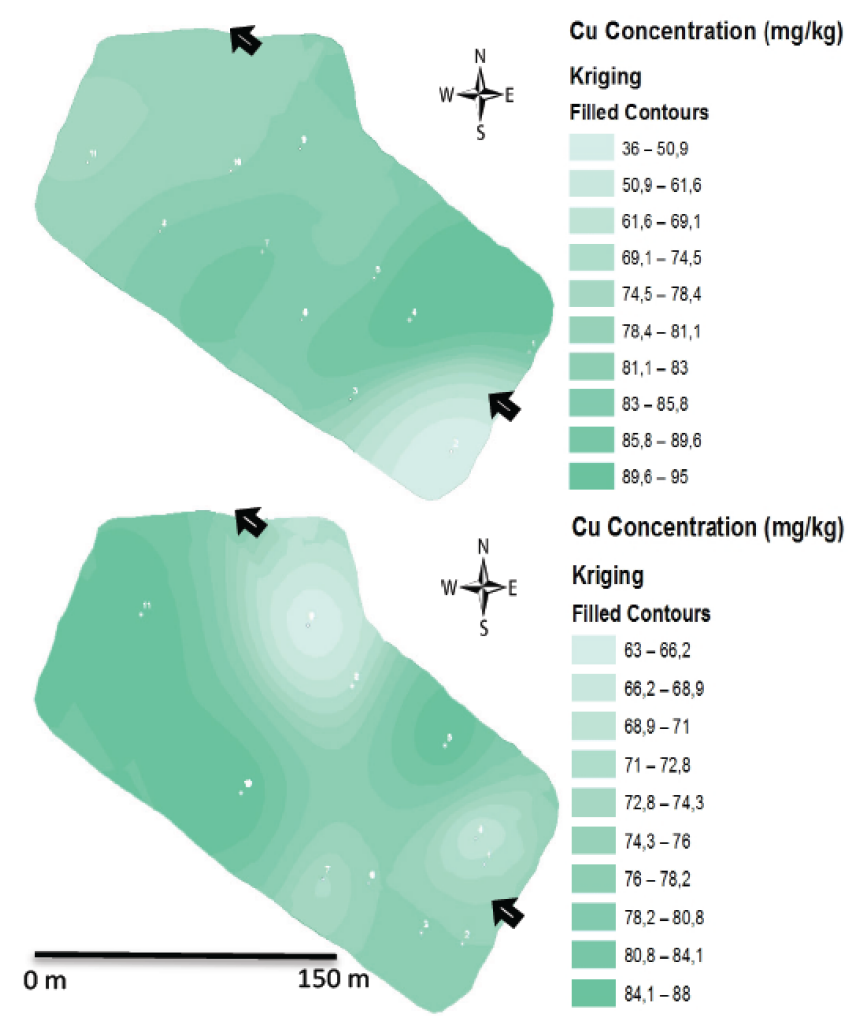

Figure 13 Spatial pattern of $\mathrm{Cu}$ in the aeration pond (upper: first sample; lower: second sample).

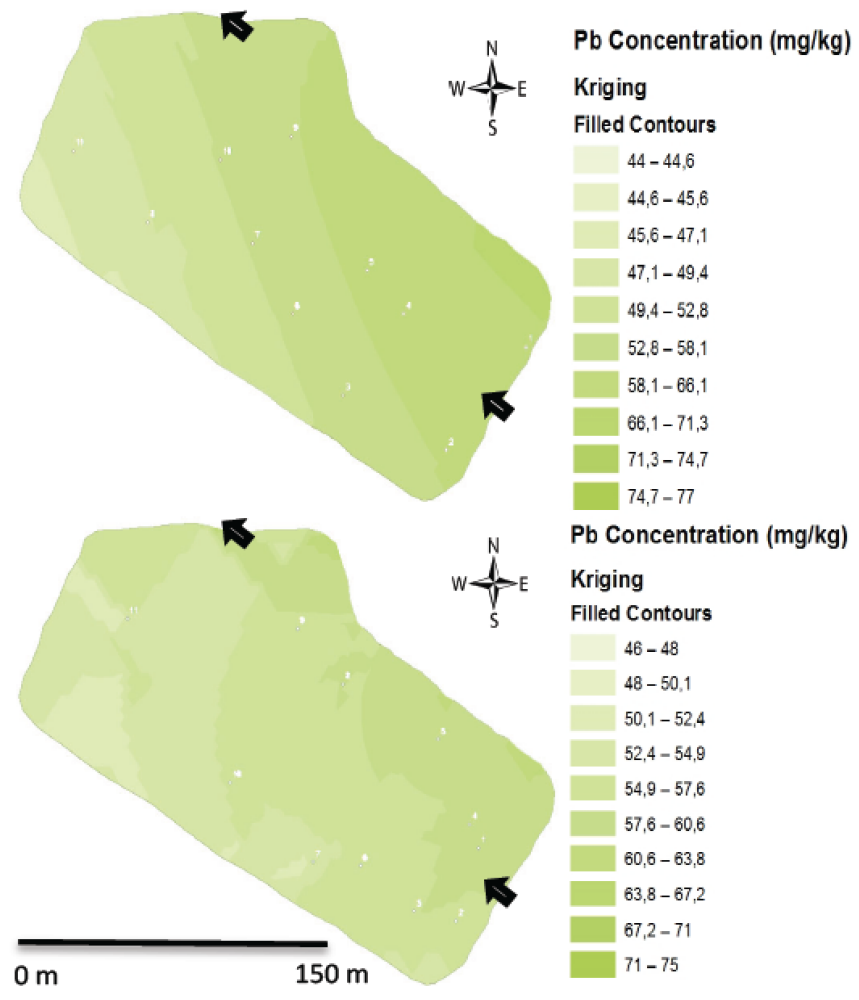

Figure 14 Spatial pattern of $\mathrm{Pb}$ in the aeration pond (upper: first sample; lower: second sample). 


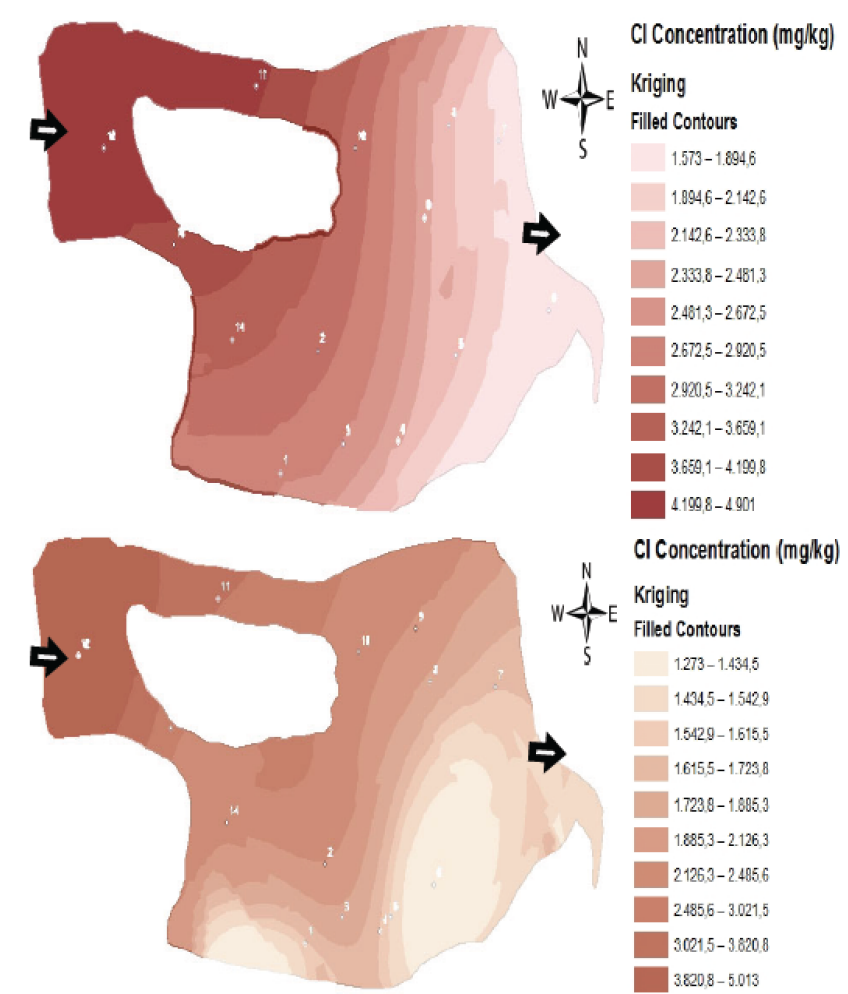

Figure 15 Spatial pattern of $\mathrm{Cl}$ in the evaporation pond (upper: first sample; lower: second sample).

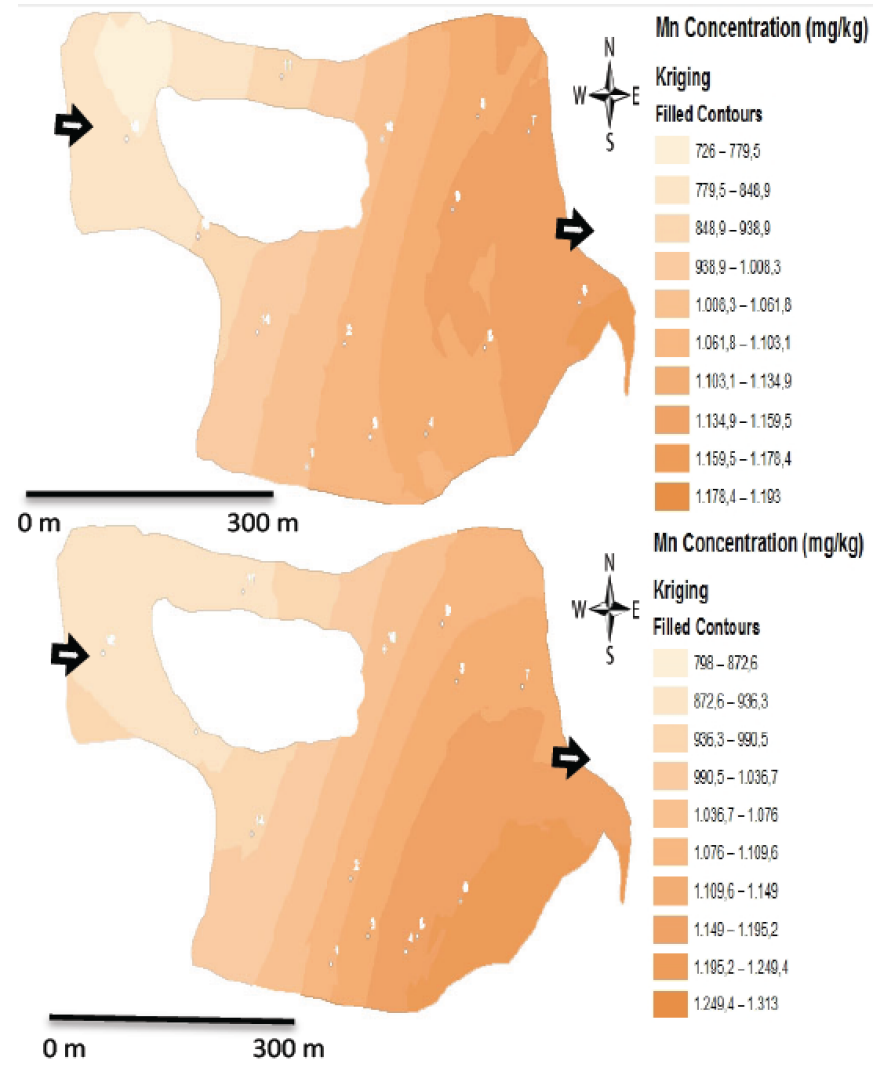

Figure 16 Spatial pattern of $\mathrm{Mn}$ in the evaporation pond (upper: first sample; lower: second sample).
The Cu patterns show that concentrations in the sediment were higher in the middle and the east side near the influent of the aeration pond for both sample dates (although the trend is stronger for the first sample date). The second sample date also exhibited a distinct zone of lower Cu concentration near the effluent point. Lead patterns show that concentrations were higher on the east side of the aeration pond for both sample dates. The highest concentrations of $\mathrm{Pb}$ in the sediment were near the influent for both sample dates.

In the evaporation pond, metal concentrations can exhibit strong but opposite spatial trends, for example, $\mathrm{Cl}$ and $\mathrm{Mn}$ (Figures 15 and 16). Cl patterns from the two sample dates were higher near the influent of the evaporation pond, while Mn concentrations were higher near the effluent of the evaporation pond.

\subsection{Trends in Metal Levels for the Receiving Waterbody}

The metals levels in the bed sediment of the small river receiving the treated discharge from the pond system are summarized in Table 4 and Figure 17. The data in Table 4 show that, with the exception of $\mathrm{Zn}$, metals levels in the river sediment frequently exceeded LEL, while one site exceeded the SEL for Mn and two sites exceeded the SEL for $\mathrm{Cu}$.

Table 4 Metals levels in bed sediment of receiving waterbody (small river), $\mathrm{mg} / \mathrm{kg}$.

\begin{tabular}{lccccccc}
\hline Sample & $\mathrm{Cl}$ & $\mathrm{Cr}$ & $\mathrm{Mn}$ & $\mathrm{Cu}$ & $\mathrm{Zn}$ & $\mathrm{As}$ & $\mathrm{Pb}$ \\
\hline 1 & 14437 & 36 & 551 & 24 & 98 & 15 & 38 \\
2 & 5144 & 55 & 472 & 63 & 26 & 10 & 21 \\
3 & 5819 & 70 & 355 & 39 & 78 & 7 & 35 \\
4 & 11952 & 28 & 588 & 127 & 85 & 15 & 34 \\
5 & 9311 & 53 & 472 & 18 & 59 & 11 & 29 \\
6 & 10710 & 10 & 371 & 53 & 48 & 1.5 & 42 \\
7 & 12220 & 57 & 505 & 55 & 44 & 7 & 28 \\
8 & 17586 & 47 & 949 & 12 & 43 & 12 & 5.5 \\
9 & 22488 & 72 & 783 & 35 & 77 & 7 & 25 \\
10 & 16896 & 32 & 615 & 21 & 23 & 2 & 28 \\
11 & 11370 & 105 & 389 & 18 & 1.5 & 1.5 & 5.5 \\
A1 & 10551 & 31 & 481 & 37 & 124 & 14 & 55 \\
A2 & 15957 & 100 & 180 & 8 & 7 & 1.5 & 23 \\
B1 & 15151 & 40 & 760 & 34 & 80 & 7 & 5.5 \\
B2 & 9456 & 47 & 1211 & 11 & 29 & 6 & 25 \\
C1 & 4708 & 46 & 461 & 44 & 43 & 10 & 28 \\
C2 & 13212 & 23 & 692 & 147 & 134 & 10 & 58 \\
M0EE LEL & NS & 26 & 460 & 16 & 120 & 6 & 31 \\
M0EE SEL & NS & 110 & 1100 & 110 & 820 & 33 & 250 \\
\hline & & & & & & & \\
\hline
\end{tabular}

The ordinary kriging in Figure 17 indicates that levels of As, $\mathrm{Pb}$, and $\mathrm{Zn}$ generally decrease downstream from near the evaporation pond to the river mouth. Chromium levels also decrease from near the evaporation pond to approximately $0.9 \mathrm{~km}$ downstream, but then increase, with the highest levels located near the river mouth. Copper decreases from near the evaporation pond 
towards the mouth of the river, but there is an unusual hotspot near the aquaculture ponds that have been infilled. The levels of Mn show no particular spatial pattern along the river and are quite similar overall.
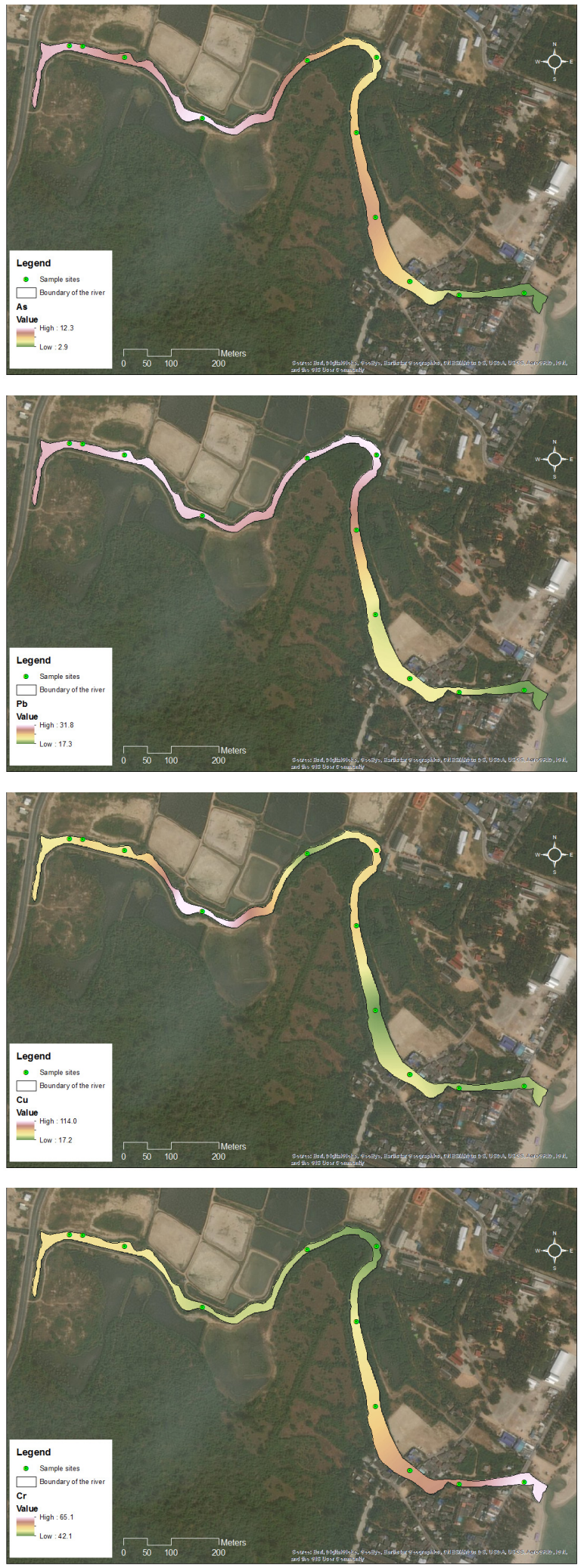
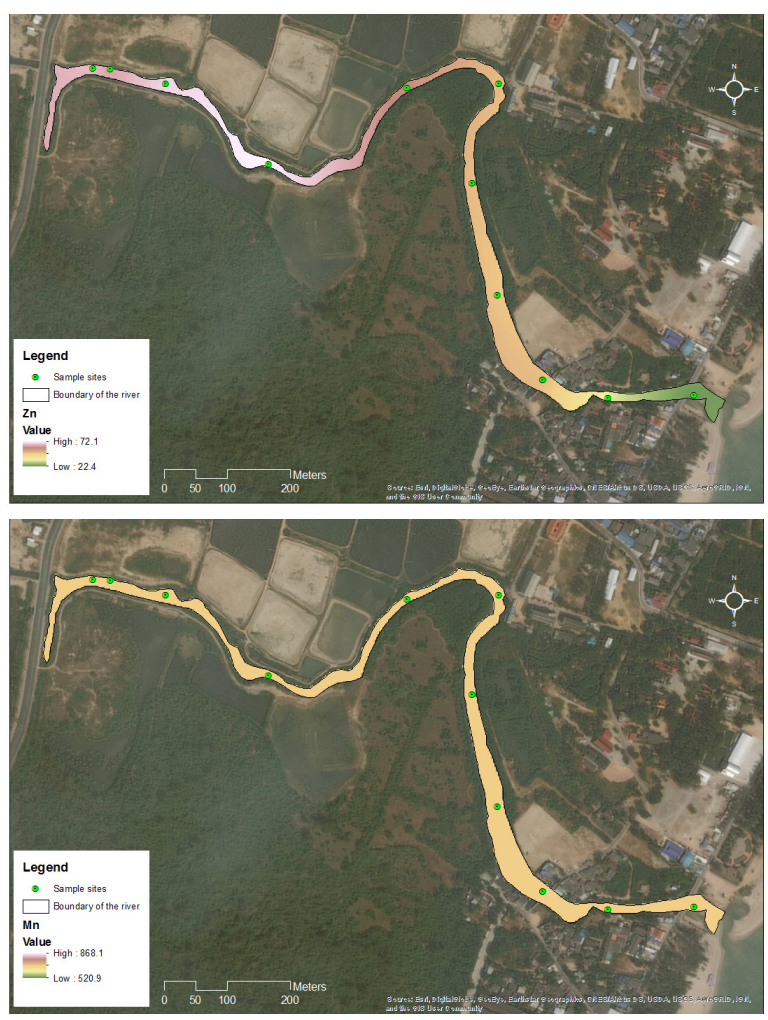

Figure 17 Ordinary kriging of metals levels in the receiving river downstream of the treatment ponds (top-bottom: $\mathrm{As}, \mathrm{Pb}, \mathrm{Cu}, \mathrm{Cr}, \mathrm{Zn}, \mathrm{Mn})$.

Table 5 compares the metals levels in the river and the evaporation pond to explore whether the pond has an impact on the receiving water.

Table 5 Metals levels in evaporation pond and upstream river sediment.

\begin{tabular}{lcc}
\hline Metal & $\begin{array}{c}\text { Evaporation Pond Concentration, Second Sample } \\
\text { Date, } \mathrm{mg} / \mathrm{kg}\end{array}$ & $\begin{array}{c}\text { Concentration, upstream-most river } \\
\text { site, } \mathrm{mg} / \mathrm{kg}\end{array}$ \\
\hline $\mathrm{Cl}$ & 2193 & 14437 \\
$\mathrm{Cr}$ & 43 & 36 \\
$\mathrm{Mn}$ & 1077 & 551 \\
$\mathrm{Cu}$ & 15 & 24 \\
$\mathrm{Zn}$ & 73 & 98 \\
$\mathrm{As}$ & 3.72 & 15 \\
$\mathrm{~Pb}$ & 30 & 38 \\
\hline
\end{tabular}

Results in Table 5 must be interpreted cautiously because of three factors. First, while the evaporation pond is at the downstream end of the treatment train, as is noted above, the upstream ponds also have a role in reducing metals levels, which is not considered in the comparison between the evaporation pond and the river.

Second, the river may be impacted by localized metal inputs. As noted, aquaculture ponds were previously located in an area near the head of the river, but these have been infilled for development. The fill consists of loose sand and some of this sand has migrated locally into the river channel. The sand might serve to 
reduce metals levels in the riverbed, although in the case of $\mathrm{Cu}$ the sand may be a local metal source and produce a hotspot. Unfortunately, the source of the sand is unknown. Levels of $\mathrm{Cr}$ appear to increase along the lower half of the river, with the highest concentrations near the mouth. Figure 17 shows that the area of increasing $\mathrm{Cr}$ coincides with the more dense urban and commercial land uses near the waterfront. It is possible that anthropogenic activities and stormwater runoff from these areas is a local source of $\mathrm{Cr}$, as higher vehicle activity (brake and tire wear), yellow street paint, and corrosion of stainless steel restaurant appliances might be sources of Cr (Adachi and Tainosho 2004; Apeagyei et al. 2011; Kaladhar et al. 2012; Tang et al. 2013).

Third, because the river discharges to the Gulf of Thailand, it will be influenced by tidal cycles and backwater effects. The tidal range in this area of Thailand is not large and some preliminary river model results using PCSWMM suggest that tidal influence is limited to the lower half of the river. However, to date we have inconsistent results from sampling the conductivity of the river water. In July 2016 , conductivity was relatively low in the upper river, in the range of $2 \mathrm{mS} / \mathrm{cm}-4 \mathrm{mS} / \mathrm{cm}$ (consistent with PCSWMM results), but in December 2016 conductivity in the upper river was $32 \mathrm{mS} / \mathrm{cm}-35 \mathrm{mS} / \mathrm{cm}$, which approaches levels found in seawater. The higher $\mathrm{Cl}$ level in the sediment for the upstream river site (Table 5) may reflect greater tidal influence during December 2016 but these dynamics need to be investigated further. Levels for the other metals in the evaporation pond and upstream river area are comparable, so this system seems to completely treat the inflow by the end of the evaporation pond. The general trend of $\mathrm{As}, \mathrm{Pb}$ and Zn concentrations decreasing in the downstream direction is consistent with transportation from the evaporation pond source area. The localized inputs of $\mathrm{Cr}$, in particular, could be influenced by tidal movements near the river mouth.

\subsection{QA-QC Analysis}

Certified reference material was run at the start of each sample batch as a QA-QC measure for the Bruker Titan S1 600 XRF unit. For the pond sediment, the Bruker CS-M2 standard was used, while for the river sediment NIST 2710a Montana I soil was used. Table 6 shows the results of QA-QC with the Bruker CS-M2 standard and Table 7 shows the results for the NIST reference material.

Table 6 QA-QC analysis for XRF with Bruker CS-M2 standard.

\begin{tabular}{lccccc}
\hline & \multicolumn{5}{c}{ Metal Concentrations (mg/kg) } \\
& As & Zn & Cr & Cu & Mn \\
\hline Bruker CS-M2 standard & 76 & 713 & 66 & 194 & 991 \\
QA-QC for the first sample date & 98 & 769 & 72 & 204 & 997 \\
QA-QC for the second sample date & 76 & 759 & 65 & 198 & 983 \\
\hline
\end{tabular}

Table 7 QA-QC results for NIST 2710a Montana I soil.

\begin{tabular}{lccccccc}
\hline & \multicolumn{7}{c}{ Metal Concentrations $(\mathrm{mg} / \mathrm{kg})$} \\
& $\mathrm{Cl}$ & $\mathrm{Cr}$ & $\mathrm{Mn}$ & $\mathrm{Cu}$ & $\mathrm{Zn}$ & $\mathrm{As}$ & $\mathrm{Pb}$ \\
\hline NIST Standard & LOD & 23 & 2140 & 3420 & 4180 & 1540 & 5520 \\
Bruker & $<$ LOD & 31 & 2023 & 3261 & 4223 & 1532 & 5692 \\
\hline
\end{tabular}

LOD: Limit of Detection; for CI LOD was $135 \mathrm{mg} / \mathrm{kg}$.
The metals levels determined for both reference materials were quite similar to the CS-M2 and NIST 2710a Montana Soils I certified reference material. Additional QA-QC was undertaken by randomly selecting five treatment pond samples from the first sample date. Three of the five selected samples were analysed with four different sample sizes (weight) and the mean values were compared with the results obtained for the corresponding samples analysed previously, to determine if the air in the sample cup affected the measurement of the metals concentrations. Tables 8 and 9 show the results of the additional QA-QC.

Table 8 Comparison of metal concentrations in five selected sediment samples with the corresponding samples analysed earlier.

\begin{tabular}{lcccccc}
\hline \multirow{2}{*}{ Sample (random) } & \multicolumn{6}{c}{ Metals Concentrations $(\mathrm{mg} / \mathrm{kg})$} \\
& As & $\mathrm{Cl}$ & $\mathrm{Zn}$ & $\mathrm{Cr}$ & $\mathrm{Cu}$ & $\mathrm{Mn}$ \\
\hline A1 136 (7 gr) & 18 & 4109 & 417 & 30 & 78 & 983 \\
A1 136 (6 gr) & 18 & 4309 & 403 & 25 & 81 & 950 \\
A1 136 (5 gr) & 28 & 4344 & 391 & 14 & 81 & 1016 \\
A1 136 (4 gr) & 20 & 4295 & 427 & 31 & 98 & 993 \\
A1 136 (earlier sample) & 18 & 4236 & 416 & 41 & 81 & 966 \\
A2 158 (7 gr) & 11 & 3094 & 130 & 24 & 35 & 890 \\
A2 158 (6 gr) & 10 & 3030 & 142 & 24 & 31 & 937 \\
A2 158 (5 gr) & 14 & 3059 & 123 & 9 & 29 & 920 \\
A2 158 (4 gr) & 12 & 3180 & 126 & 34 & 30 & 847 \\
A2 158 (earlier sample) & 10 & 3080 & 131 & 24 & 34 & 878 \\
A3 163 (7 gr) & 4 & 1013 & 49 & 49 & 15 & 2392 \\
A3 163 (6 gr) & 8 & 1028 & 50 & 69 & 19 & 2378 \\
A3 163 (5 gr) & 3 & 868 & 46 & 54 & 14 & 2405 \\
A3 163 (4 gr) & 10 & 842 & 45 & 41 & 21 & 2241 \\
A3 163 (earlier sample) & 10 & 1034 & 44 & 51 & 14 & 2422 \\
A3 171 & 13 & 2154 & 55 & 24 & 20 & 3077 \\
A3 171 (earlier sample) & 11 & 2150 & 51 & 15 & 20 & 2923 \\
A4 185 & 17 & 3187 & 76 & 35 & 17 & 995 \\
A4 185 (earlier sample) & 15 & 3336 & 71 & 30 & 16 & 1054 \\
\hline
\end{tabular}

Table 9 Comparison of metals (expressed as a percentage difference of the earlier sample) in the five selected sediment samples with different masses.

\begin{tabular}{lcccccc}
\hline \multirow{2}{*}{ Sample (Random) } & \multicolumn{6}{c}{ QA-QC after Analyzing the Samples (\%) } \\
& As & Cl & Zn & Cr & Cu & Mn \\
\hline A1 136 (7 gr) & 100 & 97 & 100 & 73 & 96 & 102 \\
A1 136 (6 gr) & 100 & 102 & 97 & 61 & 100 & 98 \\
A1 136 (5 gr) & 156 & 103 & 94 & 34 & 100 & 105 \\
A1 136 (4 gr) & 111 & 101 & 103 & 76 & 121 & 103 \\
A2 158 (7 gr) & 110 & 100 & 99 & 100 & 103 & 101 \\
A2 158 (6 gr) & 100 & 98 & 108 & 100 & 91 & 107 \\
A2 158 (5 gr) & 140 & 99 & 94 & 38 & 85 & 105 \\
A2 158 (4 gr) & 120 & 103 & 96 & 142 & 88 & 96 \\
A3 163 (7 gr) & 40 & 98 & 111 & 96 & 107 & 99 \\
A3 163 (6 gr) & 80 & 99 & 114 & 135 & 136 & 98 \\
A3 163 (5 gr) & 30 & 84 & 105 & 106 & 100 & 99 \\
A3 163 (4 gr) & 100 & 81 & 102 & 80 & 150 & 93 \\
A3 171 & 118 & 100 & 108 & 160 & 100 & 105 \\
A4 185 & 113 & 96 & 107 & 117 & 106 & 94 \\
\hline
\end{tabular}


The percentages in Table 9 show the differences between the metals concentrations in different sample sizes and the metals concentrations obtained for the corresponding earlier samples. The results show that most of the differences were not large between the five selected samples with four different sample sizes (weight) and the corresponding samples analysed earlier.

\section{Conclusions}

With the exception of $\mathrm{Cr}$, metals levels in the sediment of the aerated lagoon system tended to decrease moving from the head of the system towards the outlet. The sediment in the ponds, on average, was lightly contaminated by all metals (i.e. exceeded $\mathrm{LEL})$, although $\mathrm{Cu}$ and $\mathrm{Pb}$, on average, were less than $\mathrm{LEL}$ in the evaporation pond. Only individual samples of Mn exceeded the SEL guideline. Ordinary kriging identified spatial trends in metals levels that might be considered should the sediment be dredged and recycled for agricultural purposes. For example, Pb levels were higher on the eastern side of the aeration pond than in other parts of the pond and such areas with elevated levels need to be handled with greater care.

With the exception of $\mathrm{Zn}$, metals levels in the river sediment frequently exceeded LEL, while one site exceeded SEL for $\mathrm{Mn}$ and two sites exceeded SEL for $\mathrm{Cu}$. Metals levels in the upper reach of the river tended to be similar to those observed in the evaporation pond and decreased downstream towards the Gulf of Thailand. This trend is consistent with the treatment ponds being the source area. There are some local hotspots for metals and $\mathrm{Cr}$, in particular, showed a reverse trend to the downstream decrease in metal levels. The levels of $\mathrm{Cr}$ were greatest near the mouth of the river and likely reflect local inputs from the more dense residential and commercial area near the waterfront.

The handheld XRF unit is a useful tool to rapidly provide accurate levels of total metals in sediment. This is particularly attractive, in combination with geospatial visualization techniques, for identifying hotspot areas and supporting sediment management decisions. It should be noted, however, that XRF analysis provides data only on total metal levels, and is therefore a less powerful indicator of potential toxicity and adverse health effects. To address this shortcoming, some type of sequential extraction should be conducted on the sediment to assess the relative mobility of particle-associated metals (Amir et al. 2005; Lee et al. 2005; Irvine et al. 2009; Nemati et al. 2011; Liang et al. 2013).

\section{Acknowledgment}

Funding for this research was provided by the Norwegian Scholarship for Capacity Building Initiative for ASEAN. Thanks to Mr. Anant Bootengchan at the Cha am Municipality Wastewater Treatment Ponds System for his kind support throughout this research work.

We would like to dedicate this paper to the loving memory of the first author, Vicko Andreas, who unexpectedly passed away during the course of the review process for this paper. His relent- less pursuit for quality work, enthusiasm, and positive outlook have been instrumental in publishing this work. While missing him greatly, we remember his full-of-life character who achieved his goal of obtaining a Masters degree through his perseverance and hard work. We sincerely, believe that seeing his research published would make him happy wherever he is.

\section{References}

Adachi, K. and Y. Tainosho. 2004. "Characterization of Heavy Metal Particles Embedded in Tire Dust." Environment International 30 (8): 1009-17.

Al-Sa'ed, R. 2007. "Sustainability of Natural and Mechanized Aerated Ponds for Domestic and Municipal Wastewater Treatment in Palestine." Water International 32 (2): 310-24.

Amir, S., M. Hafidi, G. Merlina and J. C. Revel. 2005. "Sequential Extraction of Heavy Metals During Composting of Sewage Sludge." Chemosphere 59 (6): 801-10.

Apeagyei, E., M.S. Bank and J. D. Spengler. 2011. "Distribution of Heavy Metals in Road Dust along an Urban-Rural Gradient in Massachusetts." Atmospheric Environment 45 (13): 2310-23.

Bhowmick, A., K. Irvine and R. Jindal. 2017. “Mathematical Modeling of Effluent Quality of Cha am Municipality Wastewater Treatment Pond System Using PCSWMM." Journal of Water Management Modeling 25: C423. doi: 10.14796/JWMM.C423.

Bjerregaard, P., C. B. Andersen and O. Andersen. 2015. “Ecotoxicology of Metals-Sources, Transport, and Effects on the Ecosystem." In Handbook on the Toxicology of Metals, 4th edn. edited by G. Nordberg, B. Fowler and M. Nordberg, 425-59. Amsterdam: Academic Press.

Blott, S. J. and K. Pye. 2001. "GRADISTAT: A Grain Size Distribution and Statistics Package for the Analysis of Unconsolidated Sediments." Earth Surface Processes and Landforms 26:1237-48.

Bowles, J. E. 1986. Engineering Properties of Soils and Their Measurement. Singapore: McGraw-Hill.

But, K., R. Jindal, K. N. Irvine and N. Surinkul. 2016. “Investigations of Effluent Quality of Cha Am Municipality Wastewater Treatment Pond System." In 5th Sustainable Energy and Environmental Science Conference (SEES 2016), edited by A. Elsharkawy, 11-7. Singapore: Global Science \& Technology Forum.

Caeiro, S., M. Painho, P. Goovaerts, H. Costa and S. Sousa. 2003. "Spatial Sampling Design for Sediment Quality Assessment in Estuaries." Environmental Modelling \& Software 18 (10): 853-59.

Calmano, W., J. Hong and U. Förstner. 1993. "Binding and Mobilization of Heavy Metals in Contaminated Sediments Affected by $\mathrm{pH}$ and Redox Potential." Water Science and Technology. 28 (8-9): 223-35. 
Chang, K. 2012. Introduction to Geographic Information Systems, 6th ed. New York: McGraw-Hill.

Charlou, C., M. Milhe, M. Sauceau and P. Arlabosse. 2014. "A New Methodology for Measurement of Sludge Residence Time Distribution in a Paddle Dryer using X-Ray Fluorescence Analysis." Water Research Journal 69:1-8.

Chen, H., Y. Teng, S. Lu, Y. Wang and J. Wang. 2015. “Contamination Features and Health Risk of Soil Heavy Metals in China." Science of the Total Environment 512:143-53.

Chokewinyoo, P. and P. Khanayai. 2013. Wastewater Production, Treatment and Use in Thailand. 5th Regional Workshop on Safe Use of Wastewater in Agriculture, Bali. http://www.ais.unwater.org/ais/pluginfile.php/501/mod page/content/87/report thailand.pdf

Díaz, R. V., J. López-Monroy, J. Miranda and A. A. Espinosa. 2014. "PIXE and XRF Analysis of Atmospheric Aerosols from a Site in the West Area of Mexico City." Nuclear Instruments and Methods in Physics Research Section B: Beam Interactions with Materials and Atoms 318:135-8.

Droppo, I. G., D. T. Flannigan, G. G. Leppard, C. Jaskot and S. N. Liss. 1996. “Floc Stabilization for Multiple Microscopic Techniques." Applied and Environmental Microbiology 62 (9): 3508-15.

Droppo, I. G., K. N. Irvine and C. Jaskot. 2002. "Flocculation/Aggregation of Cohesive Sediments in the Urban Continuum: Implications for Stormwater Management." Environmental Technology 23 (1): 27-41.

Duong, V. N. and P. Gourbesville. 2014. “Rainfall Uncertainty in Distributed Hydrological Modelling in Large Catchments: An Operational Approach Applied to the Vu Gia-Thu Bon Catchment, Viet Nam." In 3rd IAHR Europe Congress: Book of Proceedings, 2014, Porto, Portugal. IAHR. ISBN 978-98996479-2-3.

Ferguson, C. 1992. "The Statistical Basis for Spatial Sampling of Contaminated Land." Ground Engineering 25:34.

Förstner, U. 1987. "Sediment-Associated Contaminants-An Overview of Scientific Bases for Developing Remedial Options." Hydrobiologia 149 (1): 221-46.

Förstner, U., W. Ahlf, W. Calmano and M. Kersten. 1990. "Sediment Criteria Development." In Sediments and Environmental Geochemistry, 311-38. Berlin: Springer.

Förstner, U. and W. Salomons. 1980. "Trace Metal Analysis on Polluted Sediments Part I: Assessment of Sources and Intensities." Environmental Technology Letters 1 (11): 506-17.

Förstner, U. and G. T. Wittmann. 2012. Metal Pollution in the Aquatic Environment. Berlin: Springer Science \& Business Media.

Forsythe, K. W., A. Gawedzki, P. Rodriguez, K. N. Irvine and M. Perrelli. 2013. "Geospatial Estimation of Mercury Contamination in Buffalo River Sediments." Soil and Sediment Contamination: An International Journal 22 (5): 521-31.

Forsythe, K. W., K. N. Irvine, D. M. Atkinson, M. Perrelli, J. M. Aversa, S. J. Swales, A. Gawedzki and D. J. Jakubek. 2015. “Assessing
Lead Contamination in Buffalo River Sediments." Journal of Environmental Informatics 26 (2): 106-11.

García-Delgado, M., M. S. Rodríguez-Cruz, L. F. Lorenzo, M. Arienzo and M. J. Sánchez-Martín. 2007. "Seasonal and Time Variability of Heavy Metal Content and of its Chemical Forms in Sewage Sludges from Different Wastewater Treatment Plants." Science of the Total Environment 382 (1): 82-92.

Garrett, R. G. 2000. "Natural Sources of Metals to the Environment." Human and Ecological Risk Assessment 6 (6): 945-63.

Gulliver, J. S., A. J. Erickson and P. T. Weiss. 2010. Stormwater Treatment: Assessment and Maintenance. Minneapolis, MN: University of Minnesota, St. Anthony Falls Laboratory.

Gunawardana, C., P. Egodawatta and A. Goonetilleke. 2014. “Role of Particle Size and Composition in Metal Adsorption by Solids Deposited on Urban Road Surfaces." Environmental Pollution 184:44-53.

Horowitz, A. J. 1991. A Primer on Sediment-Trace Element Chemistry. Alexandria, VA: U.S. Geological Survey. 84-2277. https://pdfs.semanticscholar.org/ba12/56aa9766c0d3e0b6ea73bb1fa9561fbcf120.pdf

Irvine, K. N., J. Caruso and G. McCorkhill. 2005. “Consideration of Metals Levels in Identifying CSO Abatement Options." Urban Water Journal 2 (3): 193-200.

Irvine, K. N., M. F. Perrelli, R. Ngoen-Klan and I. G. Droppo. 2009. "Metal Levels in Street Sediment from an Industrial City: Spatial Trends, Chemical Fractionation, and Management Implications." Journal of Soil Sediments 9:328-41.

Isaaks, E. H. 1989. Applied Geostatistics. New York: Oxford University Press.

Islam, M. S., M. K. Ahmed, M. Raknuzzaman, M. Habibullah-Al-Mamun and M. K. Islam. 2015. "Heavy Metal Pollution in Surface Water and Sediment: A Preliminary Assessment of an Urban River in a Developing Country." Ecological Indicators 48:282-91.

Jamali, M. K., T. G. Kazi, M. B. Arain, H. I. Afridi, N. Jalbani, G. A. Kandhro, A. Q. Shah and J. A. Baig. 2009. "Heavy Metal Accumulation in Different Varieties of Wheat (Triticum aestivum L.) Grown in Soil Amended with Domestic Sewage Sludge." Journal of Hazardous Materials 164 (2-3): 1386-91.

Kaladhar, M., K. V. Subbaiah and C. S. Rao. 2012. "Machining of Austenitic Stainless Steels-A Review." International Journal of Machining and Machinability of Materials 12 (1-2): 178-92.

Karvelas, M., A. Katsoyiannis and C. Samara. 2003. “Occurrence and Fate of Heavy Metals in the Wastewater Treatment Process." Chemosphere 53 (10): 1201-10.

Khaledian, Y., P. Pereira, E. C. Brevik, N. Pundyte and D. Paliulis. 2017. "The Influence of Organic Carbon and pH on Heavy Metals, Potassium, and Magnesium Levels in Lithuanian Podzols." Land Degradation and Development 28:345-54. 
Khan, S., Q. Cao, Y. M. Zheng, Y. Z. Huang and Y. G. Zhu. 2008. "Health Risks of Heavy Metals in Contaminated Soils and Food Crops Irrigated with Wastewater in Beijing, China." Environmental Pollution 152 (3): 686-92.

Kibria, G., M. M. Hossain, D. Mallick, T. C. Lau and R. Wu. 2016. "Monitoring of Metal Pollution in Waterways across Bangladesh and Ecological and Public Health Implications of Pollution." Chemosphere 165:1-9.

Koko, S., K. Irvine, R. Jindal and R. Thongdara. 2017. “Spatial and Temporal Variations of Dissolved Oxygen in Cha Am Municipality Wastewater Treatment Ponds Using GIS Kriging In-terpolation." Journal of Water Management Modeling 25: C427. doi: 10.14796/JWMM.C427.

Kumar, V. and A. K. Chopra. 2014. "Accumulation and Translocation of Metals in Soil and Different Parts of French Bean (Phaseolus vulgaris L.) Amended with Sewage Sludge." Bulletin of Environmental Contamination and Toxicology 92 (1): 103-8.

Laslett, G. M. 1994. “Kriging and Splines: An Empirical Comparison of their Predictive Performance in Some Applications." Journal of the American Statistical Association 89 (426): 391-400.

Latare, A. M., O. Kumar, S. K. Singh and A. Gupta. 2014. “Direct and Residual Effect of Sewage Sludge on Yield, Heavy Metals Content and Soil Fertility under Rice-Wheat System." Ecological Engineering 69:17-24.

Lawryk, N. J., H. A. Feng and B. T. Chen. 2009. “Laboratory Evaluation of a Field-Portable Sealed Source X-Ray Fluorescence Spectrometer for Determination of Metals in Air Filter Samples." Journal of Occupational and Environmental Hygiene 6 (7): 433-45.

Lee, P. K., Y. H. Yu, S. T. Yun and B. Mayer. 2005. "Metal Contamination and Solid Phase Partitioning of Metals in Urban Roadside Sediments." Chemosphere 60 (5): 672-89.

Li, J. and A. D. Heap. 2014. "Spatial Interpolation Methods Applied in the Environmental Sciences: A Review." Environmental Modelling \& Software 53:173-89.

Li, X., W. Zheng and W. R. Kelly. 2013. “Occurrence and Removal of Pharmaceutical and Hormone Contaminants in Rural Wastewater Treatment Lagoons." Science of the Total Environment 445:22-8.

Li, X. Y. and S. F. Yang. 2007. “Influence of Loosely Bound ExtracelIular Polymeric Substances (EPS) on the Flocculation, Sedimentation and Dewaterability of Activated Sludge." Water Research 41 (5): 1022-30.

Liang, X., X.-A. Ning, G. Chen M. Lin, J. Liu and Y. Wang. 2013. “Concentrations and Speciation of Heavy Metals in Sludge from Nine Textile Dyeing Plants." Ecotoxicology and Environmental Safety 98:128-34.

Liao, B. Q., D. G. Allen, G. G. Leppard, I. G. Droppo and S. N. Liss. 2002. "Interparticle Interactions Affecting the Stability of Sludge Flocs." Journal of Colloid and Interface Science 249 (2): 372-80.
Lim, S., T. Murphy, K. Wilson and K. N. Irvine. 2015. "Leaded Paint in Cambodia-Pilot-scale Assessment." Journal of Health and Pollution 5 (9): 18-24.

Mantler, M. and M. Schreiner. 2000. “X-Ray Fluorescence Spectrometry in Art and Archaeology." X-ray Spectrometry 29 (1): 3-17.

Martinez, E. J., J. G. Rosas, A. Morán and X. Gómez. 2015. “Effect of Ultrasound Pretreatment on Sludge Digestion and Dewatering Characteristics: Application of Particle Size Analysis." Water 7:6483-95.

Maslennikova, S., N. Larina and S. Larin. 2012. "The Effect of Sediment Grain Size on Heavy Metal Content." Lakes, Reservoirs and Ponds 6 (1): 43-54.

McBride, M. B. 2003. "Toxic Metals in Sewage Sludge-Amended Soils: Has Promotion of Beneficial Use Discounted the Risks?" Advances in Environmental Research 8 (1): 5-19.

McGrew, J. C., Jr and C. B. Monroe. 2009. An Introduction to Statistical Problem Solving in Geography. Long Grove, IL: Waveland Press.

MOEE (Ministry of Environment and Energy). 1993. Guidelines for the Protection and Management of Aquatic Sediment Quality in Ontario. Toronto: Queen's Printer for Ontario.

Murphy, T., S. Kim, P. Chanra, S. Lim, K. Wilson, K. N. Irvine and L. Allen. 2015. "Mercury Contamination of Skin-Whitening Creams in Phnom Penh, Cambodia." Journal of Health and Pollution 5 (9): 33-46.

Murphy, T., S. Lim, S. P. Huong, K. Irvine, S. Bayen, B. C. Kelly and K. Wilson. 2012. "Application of Handheld X-Ray Fluorescence Analysers to Identify Mercury in Skin-Whitening Creams in Cambodia." Journal of Health and Pollution 2 (3): 21-31.

Murphy, T., K. Phan, E. Yumvihoze, K. Irvine, K. Wilson, D. Lean, A. Poulain, B. Laird and L. H. M. Chan. 2018. "Effects of Arsenic, Iron and Fertilizers in Soil on Rice in Cambodia." Journal of Health and Pollution 8 (19): 180910. https://doi.org/10.5696/2156-9614-8.19.180910

Murray, K. S., D. Cauvet, M. Lybeer and J. C. Thomas. 1999. “Particle Size and Chemical Control of Heavy Metals in Bed Sediment from the Rouge River, Southeast Michigan." Environmental Science \& Technology 33 (7): 987-92.

Nasirian, H., K. N. Irvine, S. M. T. Sadeghi, A. H. Mahvi and S. Nazmara. 2016. "Assessment of Bed Sediment Metal Contamination in the Shadegan and Hawr Al Azim Wetlands, Iran." Environmental Monitoring and Assessment 188 (2): 107.

Nemati, K., N. K. A. Bakar, M. R. Abas and E. Sobhanzadeh. 2011. "Speciation of Heavy Metals by Modified BCR Sequential Extraction Procedure in Different Depths of Sediments from Sungai Buloh, Selangor, Malaysia." Journal of Hazardous Materials 192 (1): 402-10.

Ning, S. K., N. B. Chang, K. Y. Jeng and Y. H. Tseng. 2006. "Soil Erosion and Non-Point Source Pollution Impacts Assessment with the Aid of Multi-Temporal Remote Sensing Images." Journal of Environmental Management 79 (1): 88-101. 
Nriagu, J. O. and J. M. Pacyna. 1988. "Quantitative Assessment of Worldwide Contamination of Air, Water and Soils by Trace Metals." Nature 333 (6169): 134-9.

Pacyna, J. M. and E. G. Pacyna. 2001. "An Assessment of Global and Regional Emissions of Trace Metals to the Atmosphere from Anthropogenic Sources Worldwide." Environmental Reviews 9 (4): 269-98.

Pavão, C. G., G. S. França, G. S. Marotta, P. H. B. J. Menezes, G. B. S. Neto and H. L. Roig. 2012. "Spatial Interpolation Applied a Crustal Thickness in Brazil." Journal of Geographic Information System 4 (2): 142-52.

Pereira, P., A. J. D. Ferreira, P. Sarah, A. Cerda, R. Walsh and S. Keesstra. 2016. "Preface: Urban Soils and Sediments." Journal of Soils and Sediments 16:2493-9.

Perez-Esteban, J., C. Escolastico, A. Masaguer, C. Vargas and A. Moliner. 2014. "Soluble Organic Carbon and pH of Organic Amendments Affect Metal Mobility and Chemical Speciation in Mine Soils." Chemosphere 103:164-71. https://doi.org/10.1016/j.chemosphere.2013.11. 055

Radu, T. and D. Diamond. 2009. “Comparison of Soil Pollution Concentrations Determined Using AAS and Portable XRF Techniques." Journal of Hazardous Materials 171 (1): 1168-71.

Rhoads, B. L. and R. A. Cahill. 1999. “Geomorphological Assessment of Sediment Contamination in an Urban Stream System. Applied Geochemistry 14 (4): 459-83.

Robertson, G. P. 2008. GS+: Geostatistics for the Environmental Sciences. Plainwell, MI: Gamma Design Software.

Schmitt, P., A. Pallares, P. Francois and M.-N. Pons. 2011. "Suspended Particles in Wastewater: Acoustical Characterization and Modeling." Water Science and Technology 63 (2): 43-6.

Sereyrath, L., K. N. Irvine, T. P. Murphy and K. Wilson. 2016. “Sediment-Associated Metals Levels along the Sewer-Natural Treatment Wetland Continuum, Phnom Penh, Cambodia." Urban Water Journal 13 (8): 819-29.

Shuttleworth, E. L., M. G. Evans, S. M. Hutchinson and J. J. Rothwell. 2014. "Assessment of Lead Contamination in Peatlands Using Field Portable XRF." Water, Air, \& Soil Pollution 225 (2): 1844.

Singh, A. K., S. I. Hasnain and D. K. Banerjee. 1999. "Grain Size and Geochemical Partitioning of Heavy Metals in Sediments of the Damodar River, a Tributary of the Lower Ganga, India." Environmental Geology 39 (1): 90-8.

Soffianian, A. R., H. B. Bakir and L. Khodakarami. 2015. “Evaluation of Heavy Metals Concentration in Soil Using GIS, RS and Geostatistics." IOSR Journal of Environmental Science, Toxicology and Food Technology 9 (12): 61-72.

Sparks, D. L. 2005. "Toxic Metals in the Environment: The Role of Surfaces." Elements 1 (4): 193-7.

Suciu, I., C. Cosma, M. Todica, S. D. Bolboaca and L. Jantschi. 2008. "Analysis of Soil Heavy Metal Pollution and Pattern in Central Transylvania." International Journal of Molecular Sciences 9 (4): 434-53.

Szökefalvi-Nagy, Z., I. Demeter, A. Kocsonya and I. Kovács. 2004. "Non-Destructive XRF Analysis of Paintings." Nuclear Instruments and Methods in Physics Research Section B: Beam Interactions with Materials and Atoms 226 (1): 53-9.

Tang, R., K. Ma, Y. Zhang and Q. Mao. 2013. “The Spatial Characteristics and Pollution Levels of Metals in Urban Street Dust of Beijing, China." Applied Geochemistry 35:88-98.

Taylor, K. G. and P. N. Owens. 2009. "Sediments in Urban River Basins: A Review of Sediment-Contaminant Dynamics in an Environmental System Conditioned by Human Activities." Journal of Soils and Sediments 9 (4): 281-303.

Tchounwou, P. B., C. G. Yedjou, A. K. Patlolla and D. J. Sutton. 2012. Heavy Metal Toxicity and the Environment. In Molecular, Clinical and Environmental Toxicology, edited by A. Luch, 133-64. Basel: Springer.

Tiwari, K. K., N. K. Singh, M. P. Patel, M. R. Tiwari and U. N. Rai. 2011. "Metal Contamination of Soil and Translocation in Vegetables Growing under Industrial Wastewater Irrigated Agricultural Field of Vadodara, Gujarat, India." Ecotoxicology and Environmental Safety 74 (6): 1670-7.

TMD (Thailand Meteorological Department). 2016a. Monthly Weather Summary in Thailand, September 2016. Thailand: TMD.

TMD (Thailand Meteorological Department). 2016b. Monthly Weather Summary in Thailand, October 2016. Thailand: TMD.

Tóth, G., T. Hermann, M. R. Da Silva and L. Montanarella. 2016. "Heavy Metals in Agricultural Soils of the European Union with Implications for Food Safety." Environment International 88:299-309.

Vermette, S. J., K. N. Irvine and J. J. Drake. 1987. “Elemental and Size Distribution Characteristics of Urban Sediments: Hamilton, Canada." Environmental Technology 8:619-34.

Vittiglio, G., S. Bichlmeier, P. Klinger, J. Heckel, W. Fuzhong, L. Vincze and D. Jembrih-Simbürger. 2004. "A Compact $\mu-X R F$ Spectrometer for (In Situ) Analyses of Cultural Heritage and Forensic Materials." Nuclear Instruments and Methods in Physics Research Section B: Beam Interactions with Materials and Atoms 213:693-8.

Voltz, M. and R. Webster. 1990. “A Comparison of Kriging, Cubic Splines and Classification for Predicting Soil Properties from Sample Information." Journal of Soil Science 41 (3): 473-90.

Von Sperling, M. and C. A. de Lemos Chernicharo. 2017. Biological Wastewater Treatment in Warm Climate Regions. Seattle, WA: IWA Publishing.

Walling, D. E., P. N. Owens, J. Carter, G. J. L. Leeks, S. Lewis, A. A. Meharg and J. Wright. 2003. "Storage of Sediment-Associated Nutrients and Contaminants in River Channel and Floodplain Systems." Applied Geochemistry 18 (2): 195-220. 
Wang, C., X. Hu, M.-L. Chen and Y.-H. Wu. 2005. "Total Concentrations and Fractions of $\mathrm{Cd}, \mathrm{Cr}, \mathrm{Pb}, \mathrm{Cu}, \mathrm{Ni}$ and $\mathrm{Zn}$ in Sewage Sludge from Municipal and Industrial Wastewater Treatment Plants." Journal of Hazardous Materials 119:245-9.

Wang, S. L., X. R. Xu, Y. X. Sun, J. L. Liu and H. B. Li. 2013. “Heavy Metal Pollution in Coastal Areas of South China: A Review." Marine Pollution Bulletin 76 (1-2): 7-15.
Yu, G. H., P. J. He, L. M. Shao and P. P. He. 2008. "Stratification Structure of Sludge Flocs with Implications for Dewaterability." Environmental Science \& Technology 42 (21): 7944-9.

Zhou, Q., J. Zhang, J. Fu, J. Shi and G. Jiang. 2008. “Biomonitoring: An Appealing Tool for Assessment of Metal Pollution in the Aquatic Ecosystem." Analytica Chimica Acta 606 (2): 135-50. 